\title{
EFFECT OF AUSTENITISING ON THE STRUCTURE AND PROPERTIES OF LOW-ALLOY Cr-Mo-V STEELS AFTER LONG-TERM OPERATION IN CREEP CONDITIONS FOR THE POWER INDUSTRY
}

The article concerns the revitalising heat treatment of components of the pressure part of power units operating under creep conditions. The possibilities of "recovering" the structure and functional properties similar to those of the initial state are shown on the example of elbows and straight sections made of 14MoV6-3 steel (13HMF), after long-term operation, significantly beyond the computational working time, with slightly diversified but significant exhaustion. It is possible by selecting the type and parameters of heat treatment depending on the structure class after operation and the corresponding degree of exhaustion. The effectiveness of revitalising heat treatment is shown, especially in relation to the recovery of impact resistance and creep resistance due to the obtained structure corresponding to the initial state. The defined limitation in the operation of revitalising heat treatment of materials after long-term operation in creep conditions is the structure after operation, in which the initiation of internal damages as a result of creep will be revealed.

Keywords: steels for the power industry, operation in creep conditions, revitalising heat treatment, structure and mechanical properties

\section{WPEYW AUSTENITYZOWANIA NA STRUKTURE I WEAŚCIWOŚCI NISKOSTOPOWYCH STALI Cr-Mo-V DLA ENERGETYKI DEUGOTRWALE EKSPLOATOWANYCH W WARUNKACH PEEZANIA}

\begin{abstract}
Artykuł dotyczy rewitalizującej obróbki cieplnej elementów części ciśnieniowej bloków energetycznych pracujaccych $w$ warunkach petzania. Na przykładzie kolan i odcinków prostych ze stali 14MoV6-3 (13HMF) po dtugotrwałej eksploatacji znacznie poza obliczeniowym czasem pracy, o nieco zróżnicowanym, ale znacznym stopniu wyczerpania, pokazano możliwości „odzyskania” struktury i właściwości użytkowych zbliżonych do charakterystycznych dla stanu wyjściowego. Jest to możliwe poprzez dobór rodzaju i parametrów obróbki cieplnej w zależności od klasy struktury po eksploatacji i odpowiadającego jej stopnia wyczerpania. Pokazano skuteczność rewitalizującej obróbki cieplnej, szczególnie w stosunku do odzyskania udarności i odporności na pełzanie dzięki uzyskanej strukturze odpowiadajacej charakterystycznej dla stanu wyjściowego. Zdefiniowanym ograniczeniem w stosowaniu rewitalizującej obróbki cieplnej materiałów po dtugotrwałej eksploatacji w warunkach pełzania jest struktura po eksploatacji, w której zostanie ujawnione zapoczatkowanie uszkodzeń wewnętrznych w wyniku pełzania.
\end{abstract}

Stowa kluczowe: stale dla energetyki, eksploatacja w warunkach pełzania, rewitalizująca obróbka cieplna, struktura i właściwości mechaniczne

\section{INTRODUCTION}

The article is a part of the undertaking which aims at developing a reconditioning heat treatment of components of the pressure part of a power unit working in creep conditions. It is used in the renovation and modernisation at power plants and combined power and heating plants.

This undertaking meets the expectations related to the need to extend the use of operating power units whose operating time has significantly exceeded the computational capacity. It is expected to create the possibility of further work of these units in a changed regime tailored to current needs for at least another 100,000 hours [1]. To ensure this, it is necessary to car- ry out renovation and modernisation works of a considerable scope. An important problem is then the state of the structure, which corresponds to a set of properties that do not guarantee the transfer of required operational loads resulting from the level of temperature and pressure (stress) [2,3]. Therefore, there is also the problem of welding materials after long-term operation and new materials after long-term work, which are characterised by structure and properties significantly different from those characteristic for the initial state and may not carry the required loads $[4,5]$.

The implementation of this problem is the scientific and technical basis for the complete or partial restoration of the structure and properties prior to the use of the material of pipeline components, which have been 
working in creep conditions for a time much greater than computational time. The process is defined as revitalisation. It allows for a significant extension of the safe time of further use of system components. The costs of these activities are significantly lower than the costs of producing new components of the installation.

\section{HEAT TREATMENT OF LOW-ALLOY Cr-Mo-V STEELS FOR THE POWER INDUSTRY}

The basic heat treatment of steel products made of low-alloy three-component $\mathrm{Cr}-\mathrm{Mo}-\mathrm{V}$ steels and components of pressure installations operating at elevated temperature produced therefrom consists of two thermal treatments: normalisation annealing and tempering. The required temperature range of annealing during austenitising is $940-960^{\circ} \mathrm{C}$, and $700-730^{\circ} \mathrm{C}$ during tempering. The given temperature range of heating for these procedures and the heating times used are relatively clearly defined by manufacturers of products made of these steels. On the other hand, the cooling method from the austenitising temperature is not very precise. The few provisions in standard specifications for steel products or catalogues for these steels give only general guidelines for the selection of cooling agents, i.e. a way to indirectly determine the cooling rate.

The PN-EN 10216-2:2014-02 standard [6] recommends a procedure for the type and parameters of heat treatment for steel grades belonging to this group, including for the $14 \mathrm{MoV} 6-3$ steel, which is the subject of the study. In order to achieve the required level of mechanical properties, quenching and tempering are required for a wall thickness $T$ greater than $10 \mathrm{~mm}$ or a $T / D$ ratio $>0.15,(D-$ outer diameter of the pipe). This decision remains at the discretion of the manufacturer, but it should be defined by the ordering party in the request for quotation and then formulated in the order. Steel pipes processed in such a way should be marked in the steel name with the symbol $+\mathrm{QT}$. The PN-EN 10222-2:2017-06 standard [7] recommends: "...air or oil as a cooling agent for the base section thickness $t_{r} \leq 500 \mathrm{~mm}$." In comments to heat treatment parameters for the 14MoV6-3 (13HMF) steel, the Institute for Ferrous Metallurgy in Gliwice [7] gives a different cooling agent after austenitisation depending on the thickness of the steel product, in particular: "calm air - pipes and forgings up to $50 \mathrm{~mm}$ thick; compressed air - forgings over 50 to $100 \mathrm{~mm}$ thick; oil - forgings over $100 \mathrm{~mm}$ thick." Thus, in practice, the decision belongs to the manufacturers of steel products as well as manufacturers of equipment components made of these steels that use experience and knowledge of material characteristics, including CTPc diagrams, by choosing the cooling rate. Their selection as a consequence of the dimensions and shape of the products makes it possible to achieve the level of mechanical properties required by the standard.

The author's study of low-alloy steel products for use at elevated temperatures, especially of three-component "Cr-Mo-V" steels, showed the impact of various initial state structures on significant structural differences after long-term operation in creep conditions. These issues were described in detail in the research and publications of the Institute for Ferrous Metallurgy [8] and the Institute of Power Engineering [9]. The result of their many years of research was the disclosure of a very significant inhomogeneity of the structure and corresponding mechanical properties for the material as delivered. An example may be the mechanical properties with significant differentiation of the three-component Cr-Mo-V 14MoV6-3 steel where: yield stress $R_{p 0.2}$ was in the range from 285 to $570 \mathrm{MPa}$, tensile strength $R_{m}$ in the range from 477 to $719 \mathrm{MPa}$, elongation $A$ from 14.5 to $35.7 \%$, and impact strength KCU2 from 4 to $393 \mathrm{~J} / \mathrm{cm}^{2}$.

Another issue related to heat treatment of these steels is the shaping of their structure by controlled continuous cooling from the austenitising temperature for different annealing times at tempering temperature, which is described in [10]. The main purpose of the study in this work was to determine mechanical properties using methods for heat treatment parameters modelling, and above all the impact of the structure on material cracking by determining the J-integral $J_{I C}$ and the limiting value of stress intensity factor $K_{I C}$.

The results of the referenced research work confirm that in industrial practice, cooling rates after austenitisation carried out during normalisation annealing are not clearly defined. It is the reason for the presence of steel products with a diverse structure in the initial state, resulting in a different level of mechanical properties.

Equipment or components thereof made of 14MoV6-3 $(13 \mathrm{HMF})$ steel products are subjected to heat treatment consisting in normalisation and tempering in the final stage of the technological process of their production. The annealing temperature for these thermal treatments is given in standards for steel grades, material sheets or heat treatment procedures applicable to manufacturers of the products. The applicable acceptance criterion after these thermal treatments are the mechanical properties determined during tests carried out at ambient and elevated temperatures, the required values of which are given in standard specifications and technical conditions. The structure of the material of steel products, its phase components and their form after heat treatment do not constitute a criterion for correctness of its performance in practice. Also, studies of the structure of the initial state of equipment made of low-alloy steel $\mathrm{Cr}-\mathrm{Mo}-\mathrm{V}$ are not among the required standard criteria for assessing their quality, and are implemented only per special requirements of the customer.

The subject of this study are the results of research showing the relationship between the state of microstructure and mechanical properties of the $14 \mathrm{MoV} 6-3$ (13HMF) steel, most often used in the power industry among all types of this steel group. The analysis covers both the diversity of the structure of the initial state and the state after long-term operation.

The basic heat treatment of this steel consists in normalisation with subsequent tempering, and the characteristic structure of the initial state of a steel product as well as the equipment made from it is a ferritic-pearlitic structure through ferritic-pearlitic-bainitic to ferritic-bainitic (lower bainite). This steel was first of all used for the components of power equipment working in creep conditions. Therefore, creep resistance is the most important expected performance. 

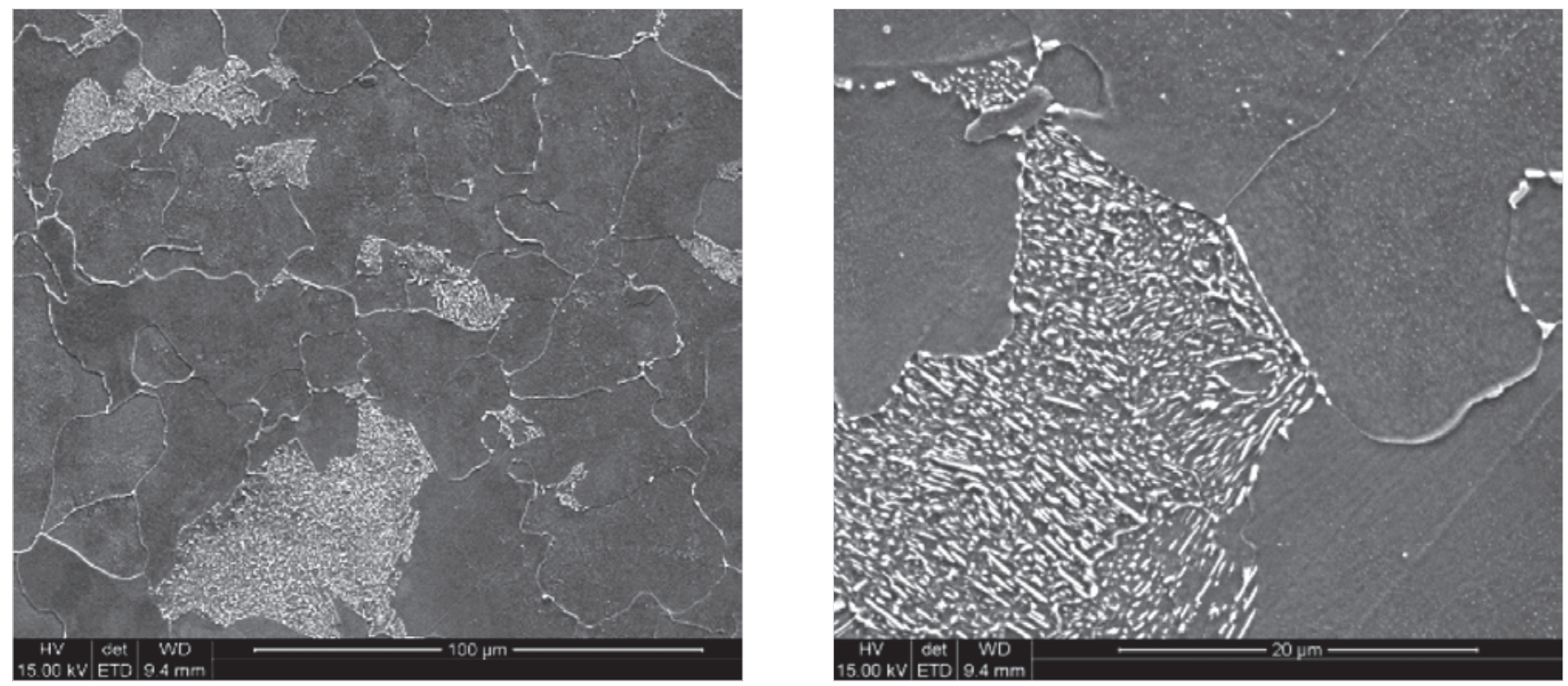

Fig. 1. Typical structure of the initial state of the 14MoV6-3 steel observed on a metallographic microsection with a scanning electron microscope

Rys. 1. Typowa struktura stanu wyjściowego stali 14MoV6-3 obserwowana na zgładzie metalograficznym w skaningowym mikroskopie elektronowym

In this steel, it is obtained at an appropriate level due to the solution hardening of ferrite, mainly by chromium and manganese, and partly molybdenum, and due to hardening through fine-dispersed precipitates of MC type carbides, whose main component is vanadium. An example of a typical initial state structure is shown in Fig. 1.

A typical application of the 14MoV6-3 steels are main steam pipelines of power units operating in creep conditions. A particular problem concerning long-term operated pipelines are the issues concerning the possibility of recovering the mechanical properties of the material with a level corresponding to the initial state of the "worn-out" component through appropriate heat treatment procedures enabling its reinstallation.

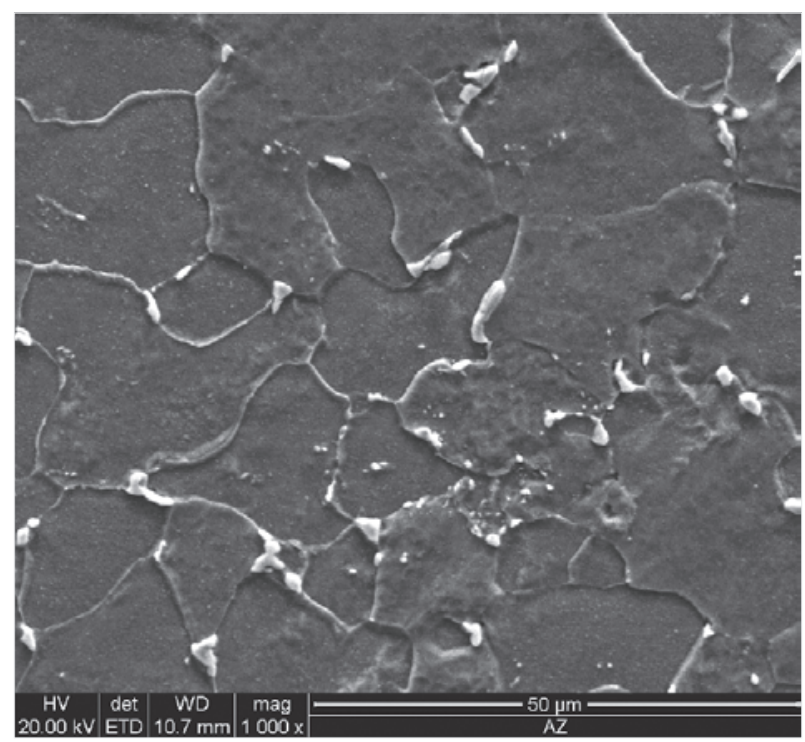

The national scientific and technical literature was reviewed in terms of the use of heat treatment of pipeline components after long-term operation in creep conditions. The review has shown only limited information and research results on these issues. This information concerns the influence of heat treatment on the functional properties of new welded joints used in long-term creep conditions in which the original materials are the 14MoV6-3 and 10CrMo9-10 low-alloy steels with a structure changed in relation to the initial state, which corresponds to a significant degree of exhaustion and material in initial condition. In only a few cases, the applied welding technologies and control procedures before and after welding distinguish structural differences of original materials that were

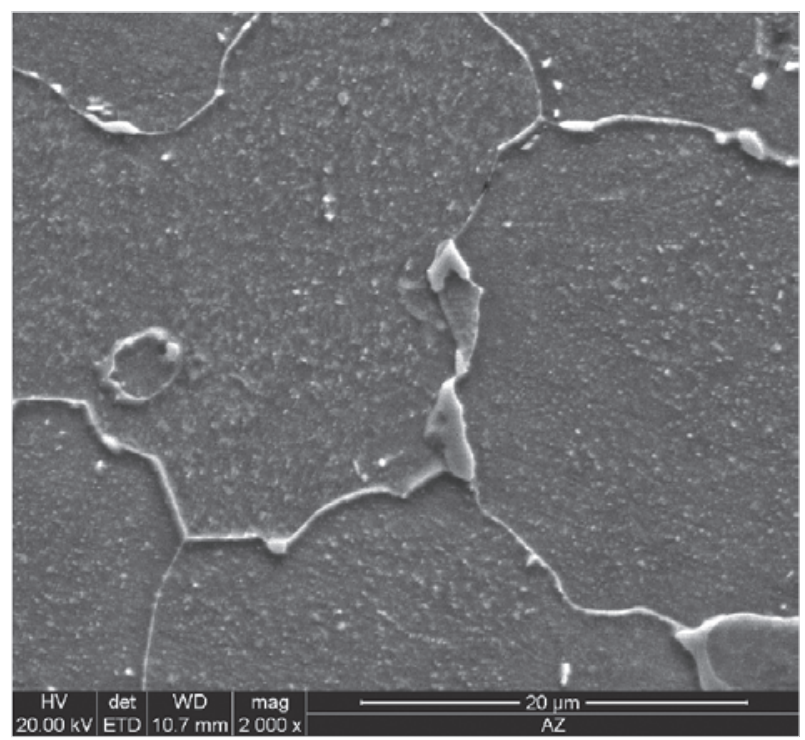

Fig. 2. Structure of the 14MoV6-3 steel after long-term use significantly beyond the computational service life observed on a metallographic microsection with a scanning electron microscope (according to the IMŻ classification, class 2/3, exhaustion rate approx. 0.4)

Rys. 2. Struktura stali 14MoV6-3 po długotrwałej eksploatacji znacznie poza obliczeniowym czasem eksploatacji obserwowana na zgładzie metalograficznym w skaningowym mikroskopie elektronowym (wg klasyfikacji IMż, klasa 2/3, stopień wyezerpania ok. 0,4) 
not used from those after use under creep conditions. The described heat treatment procedures relate mainly to stress relief annealing after welding. On the other hand, normalisation of components of pipelines for long-term operation in creep conditions is rarely described.

Heating of low-alloy steels for working at elevated temperature before normalisation, as for other steels, should ensure obtaining austenitic structure or structure consisting of austenite and insoluble precipitates [11].

The structure of the $14 \mathrm{MoV} 6-3$ steel, which is the subject of the studies, differs from the state of the structure before heating; in the initial state, it is a mixture of ferrite with bainite, and sometimes pearlite, and after long-term operation in creep conditions, it can even be ferrite with carbides. The differences in the structure state have a significant impact, mainly on the necessary heating, from $A_{c 1}$ to beyond $A_{c 3}$, and annealing time, guaranteeing the occurrence of austenitic transformation. Steels after long-term operation in creep conditions are characterised by an advanced precipitation process. In order to obtain a structure and properties similar to the initial state through heat treatment, it is necessary to dissolve the precipitates. Therefore, the main condition determining the rate of transformation $(\alpha+$ carbides $\rightarrow \gamma)$ is the diffusion of alloying elements included in the composition of the precipitates, which, forming the substitution solutions, diffuse the slowest [11]. Therefore, precipitates in low-alloy steels for working at elevated temperature, after long-term operation in creep conditions, are more stable, which makes them very difficult to dissolve in austenite, and the regeneration process of such a structure requires different annealing times than for a state similar to the initial state.

An example of the microstructure image corresponding to the final stage of stable creep of the $14 \mathrm{MoV} 6-3$ steel that has been in use for a long time is shown in Fig. 2. The structure is ferrite with fairly evenly distributed $\mathrm{MC}$ and $\mathrm{M}_{6} \mathrm{C}$ carbides precipitates inside the grains and chains of large precipitates mainly of the $\mathrm{M}_{23} \mathrm{C}_{6}$ type on their borders. Among the occurring precipitates, MC carbide, which is characterised by high affinity to carbon, is of special interest; it has a simple

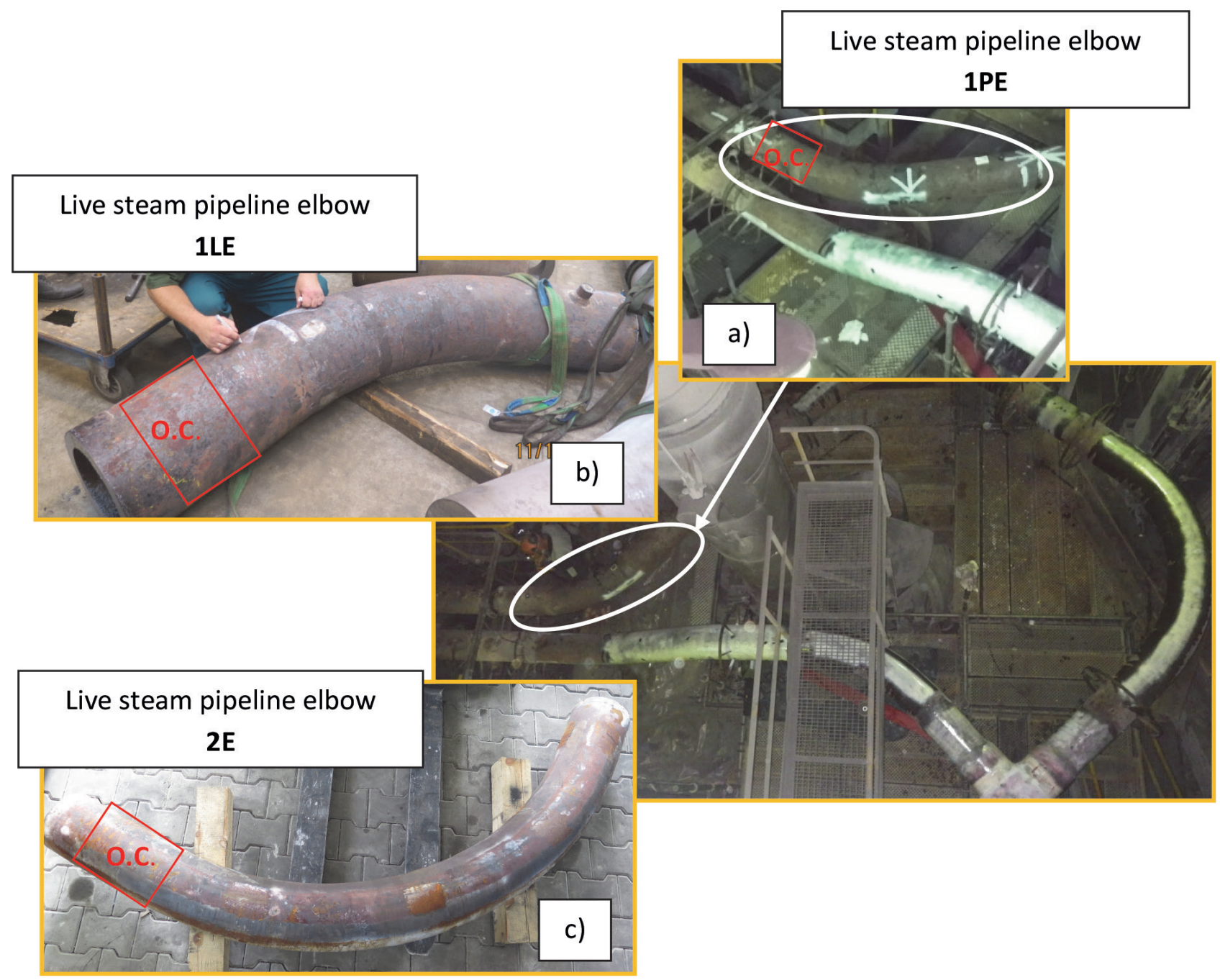

Fig. 3. Test material in the form of live steam pipeline elbows after long-term operation outside the computational working time: a) after operation for 127,000 hours - 1PE, b) after operation for 127,000 hours - 1LE, c) after operation for 228,000 hours $-2 \mathbf{E}$

Rys. 3. Materiał do badań w postaci kolan rurociagów pary świeżej po długotrwałej eksploatacji poza obliczeniowym czasem pracy: a) po eksploatacji przez 127 tys. godzin ozn. 1PE, b) po eksploatacji przez 127 tys. godzin ozn. 1LE, c) po eksploatacji przez 228 tys. godzin ozn. $2 \mathrm{E}$ 
form and is very stable, hard and sparingly soluble in austenite [12].

\section{MATERIAL FOR TESTING}

The tests were carried out for two elbows of the main live steam pipeline with the dimensions $\phi 355.6 \times 47 \mathrm{~mm}$ with a bend radius $R_{g}=1500 \mathrm{~mm}$, bending angle $\alpha=45^{\circ}$ made of steel $14 \mathrm{MoV} 63$ after 127,000 working hours at a working temperature $t_{r}=540^{\circ} \mathrm{C}$, and at a working pressure $p_{r}=18.4 \mathrm{MPa}$. In addition, two straight sections directly adjacent to the taken elbows were taken for examination. The test material in the form of elbows after 127,000 working hours is shown in Fig. 3. Fig. 3a shows elbow 1PE taken from the right side of the boiler, and Fig. $3 \mathrm{~b}$ shows elbow $1 \mathrm{LE}$ taken from the left side of the boiler.

In order to obtain a material with a different level of changes in the structure than in the material of the elbows after 127,000 hours of operation, an elbow was cut from the live steam pipeline with the dimensions of $\phi 219 \times 28 \mathrm{~mm}$, bending radius $R_{g}=1400 \mathrm{~mm}$, bending angle $\alpha=90^{\circ}$, made also of the $14 \mathrm{MoV} 63$ steel. The elbow was taken for examination after 228,000 working hours at an operating temperature $t_{r}=540^{\circ} \mathrm{C}$, and at a working pressure $p_{r}=13.4 \mathrm{MPa}$. The elbow, $2 \mathrm{E}$, after being cut out of the pipeline, is shown in Fig. 3c.

The conducted follow-up of the chemical composition of the pipeline sections material for testing showed compliance with the requirements in this respect, defined in the PN-H-84024:1975 [13] standard, in force at the time of production of the pipes from which the elbows and straight sections of the pipeline were made.

\section{STRUCTURE AND MECHANICAL PROPERTIES AFTER OPERATION OUTSIDE COMPUTATIONAL WORKING TIME}

The examination of the microstructure of materials after operation was carried out with a scanning electron microscope at magnifications up to $10,000 \times$. Their aim was to determine the degree of decomposition of pearlite/bainite areas and to reveal the degree of development of carbide precipitation processes. In addition, to determine the phase composition of precipitates, carbide types and their content, an X-ray analysis of the phase composition of the precipitate obtained with the electrolytic method as a result of matrix dissolution was carried out for each of the tested materials.

The obtained images of microstructure and designated classes of pearlite/bainite decomposition, grade of development of precipitates, class of development of internal damage as a result of creep, and main structural class and corresponding degree of exhaustion are shown in Fig. 4 and in column 8 of Table 1. The result of the assessment of the identification of precipitates and their content is presented in column 7 of Table 1 . The assessment of the condition of the material and the corresponding degree of exhaustion were carried out in accordance with the classification of the Institute for Ferrous Metallurgy [1].

For the examined materials after operation, mechanical properties were tested on selected areas of the elbows and straight sections. The obtained results of tensile strength $R_{m}$ at room temperature are shown in Fig. 5a. The results of yield stress $R_{e}$ at room temperature are shown in Fig. 5b. Elongation in the tensile test at room temperature is shown in Fig. 5c. For the

Table 1. Parameters of operation and assessment of microstructure and the degree of development of precipitation processes of carbides of the tested elbows material made of the 14MoV6-3 steel after long-term operation in creep conditions beyond computational working time

Tabela 1. Parametry eksploatacji oraz ocena mikrostruktury i stopnia rozwoju procesów wydzieleniowych węglików materiału badanych kolan ze stali 14MoV6-3 po długotrwałej eksploatacji w warunkach pełzania poza obliczeniowym czasem pracy

\begin{tabular}{|c|c|c|c|c|c|c|c|c|}
\hline 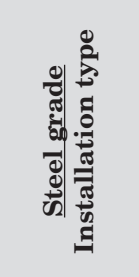 & 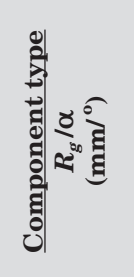 & 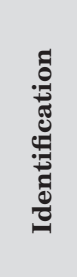 & 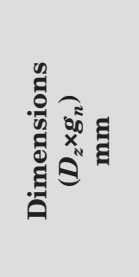 & 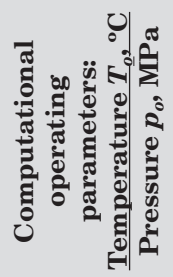 & 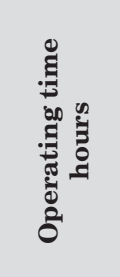 & 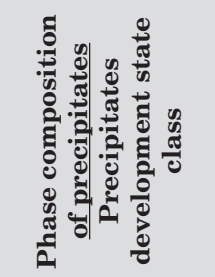 & 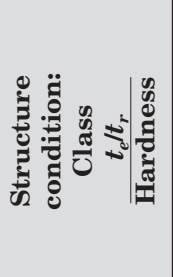 & 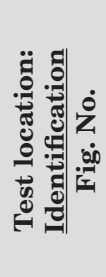 \\
\hline 1 & 2 & 3 & 4 & 5 & 6 & 7 & 8 & 9 \\
\hline \multirow{8}{*}{$\begin{array}{l}\text { 14MoV6-3 } \\
\frac{(13 \mathrm{HMF})}{\text { live steam }} \\
\text { pipeline }\end{array}$} & \multirow{2}{*}{$\begin{array}{l}\frac{\text { Elbow }}{1500 / 45} \\
\text { left side }\end{array}$} & \multirow[t]{2}{*}{$1 \mathrm{LE}$} & \multirow{6}{*}{$355.6 \times 47$} & \multirow{6}{*}{$\frac{540}{18.4}$} & \multirow{6}{*}{127,000} & $\begin{array}{c}\mathrm{M}_{23} \mathrm{C}_{6} \\
+\mathrm{MC}+\mathrm{M}_{6} \mathrm{C} \\
\end{array}$ & \multirow{2}{*}{$\begin{array}{c}\text { Class } 2 / 3 \\
\frac{0.3-0.4}{145}\end{array}$} & \multirow{2}{*}{$\frac{1 \mathrm{LE}}{\text { Fig. 1a }}$} \\
\hline & & & & & & Class a/b & & \\
\hline & \multirow{4}{*}{$\begin{array}{c}\underline{\text { Elbow }} \\
1500 / 45 \\
\text { right side }\end{array}$} & \multirow{4}{*}{$1 \mathrm{PE}$} & & & & $\mathrm{MC}+\mathrm{MC}$ & \multirow{4}{*}{$\begin{array}{c}\text { Class } 3 / 4 \\
\frac{0.5}{133}\end{array}$} & $\frac{1 \mathrm{PE} 1}{\text { Fig. 1b }}$ \\
\hline & & & & & & $\mathrm{NI}_{6} \mathrm{C}+\mathrm{N}$ & & $\frac{1 \mathrm{PE} 2}{\text { Fig. } 1 \mathrm{~b}}$ \\
\hline & & & & & & \multirow{2}{*}{ Class b } & & $\frac{1 \mathrm{PE} 3}{\text { Fig. } 1 \mathrm{~b}}$ \\
\hline & & & & & & & & $\frac{1 \mathrm{PE} 4}{\text { Fig. 1b }}$ \\
\hline & \multirow{2}{*}{$\frac{\text { Elbow }}{1400 / 90}$} & \multirow{2}{*}{$2 \mathrm{E}$} & \multirow{2}{*}{$219 \times 28$} & \multirow{2}{*}{$\frac{540}{13.8}$} & \multirow{2}{*}{228,000} & $\mathrm{M}_{3} \mathrm{C}+\mathrm{MC}+\mathrm{M}_{23} \mathrm{C}_{6}$ & \multirow{2}{*}{$\begin{array}{c}\text { Class } 1 / 2 \\
\frac{0.2-0.3}{150}\end{array}$} & \multirow{2}{*}{$\stackrel{2 \mathrm{E}}{\text { Fig. 1c }}$} \\
\hline & & & & & & Class a & & \\
\hline
\end{tabular}




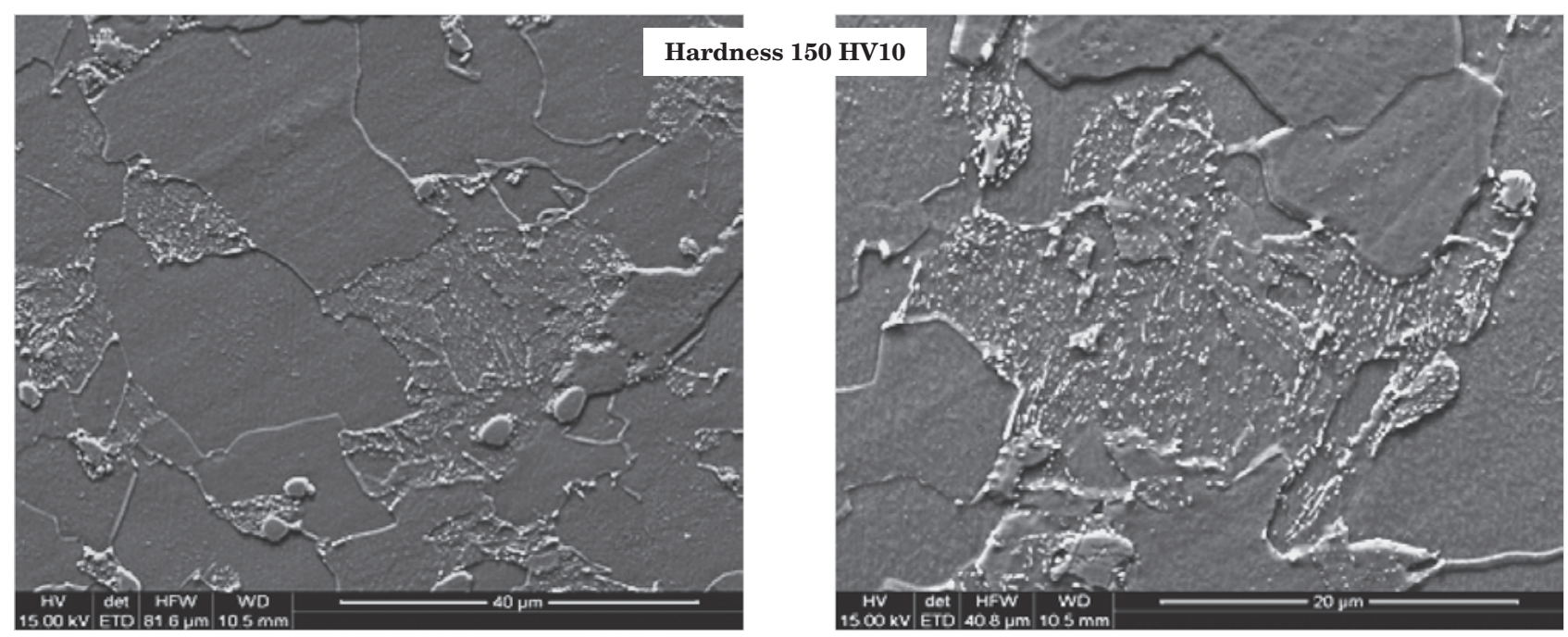

Pearlite/bainite areas: class I; precipitates: class a; damage processes: class 0

MATERIAL CONDITION: CLASS 1/2; EXHAUSTION DEGREE: 0.2-0.3

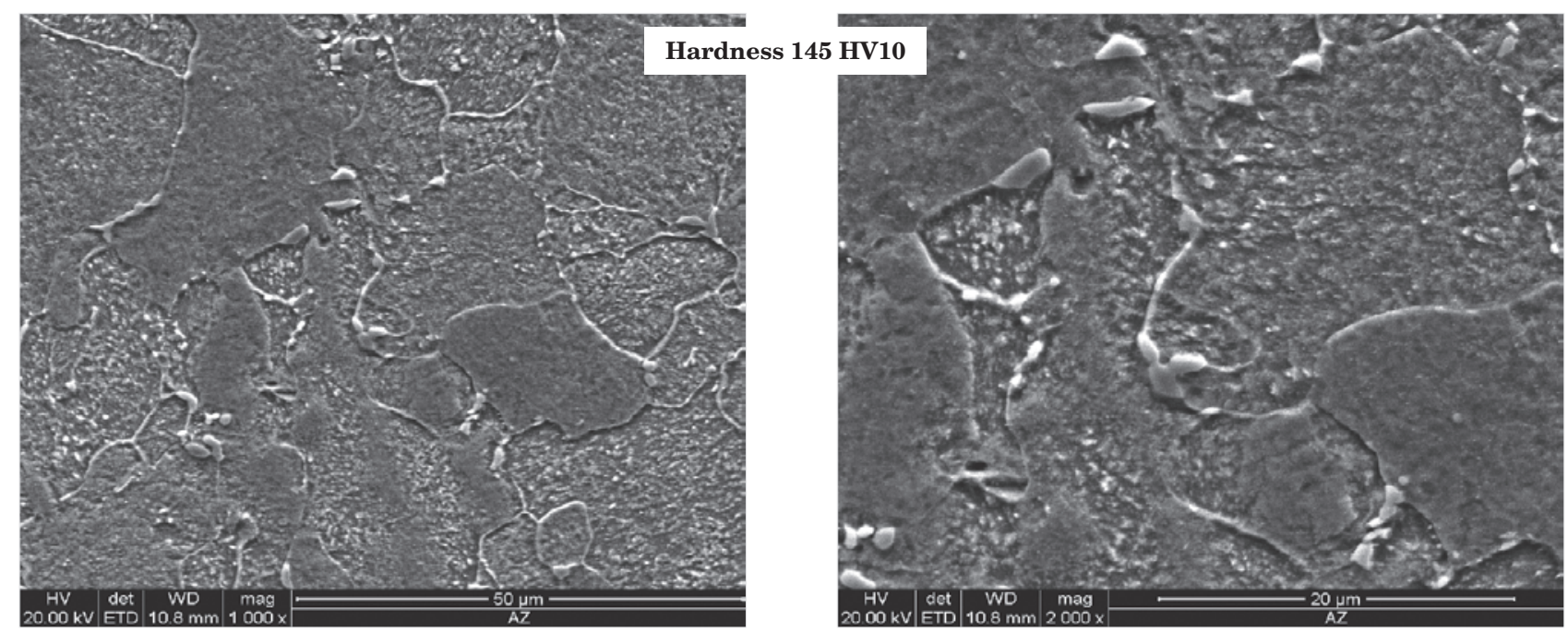

Bainitic areas: class I/II; precipitates: class a/b; damage processes: class 0

MATERIAL CONDITION: CLASS 2/3; EXHAUSTION DEGREE: 0.3-0.4

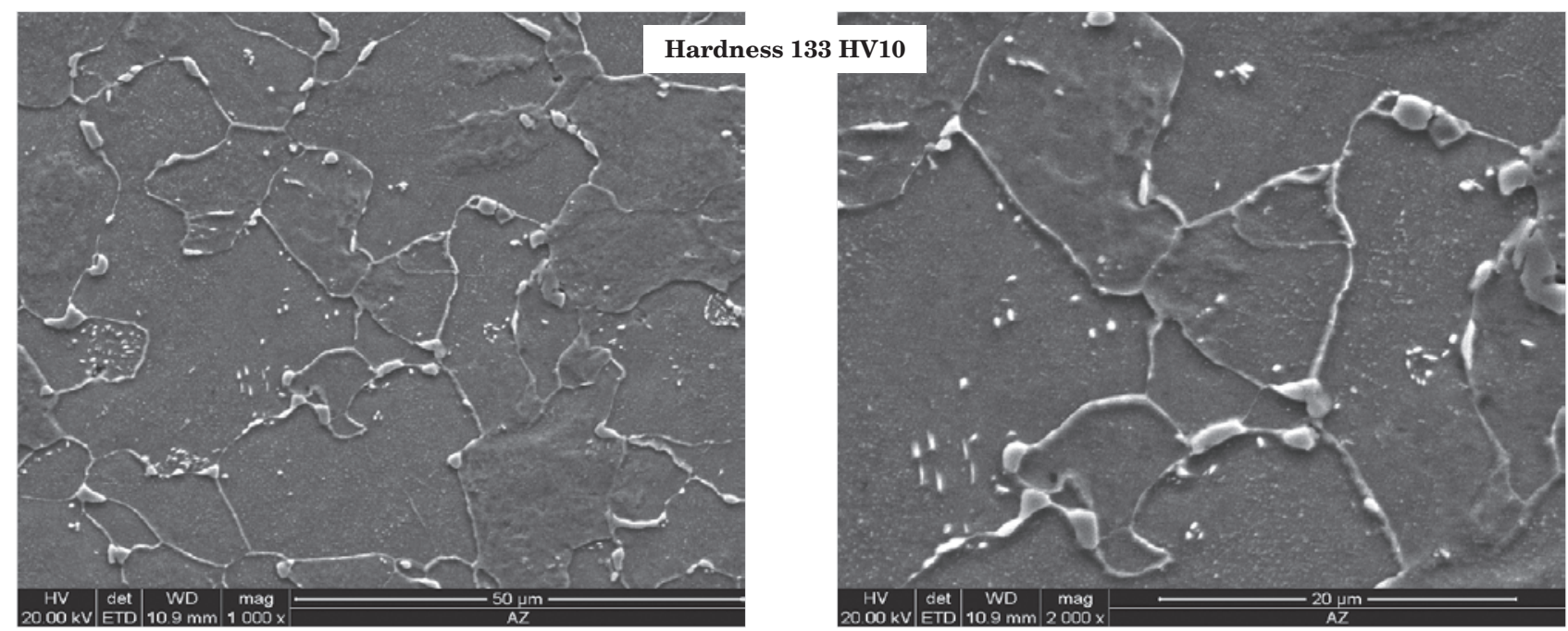

Bainitic areas: class II; precipitates: class b; damage processes: class 0/A

MATERIAL CONDITION: CLASS 3/4; EXHAUSTION DEGREE: 0.5

Fig. 4. Microstructure of the 14MoV6-3 (13HMF) steel of the tested elbows after long-term operation in creep conditions with an evaluation of the material condition and degree of exhaustion: a) $2 \mathrm{E}$ elbows after 228,000 hours of operation, b) 1LE elbows after 127,000 hours of operation, c) 1PE elbows after 127,000 hours of operation

Rys. 4. Obrazy mikrostruktury stali 14MoV6-3 (13HMF) badanych kolan po długotrwałej eksploatacji w warunkach pełzania z oceną stanu materiału i stopnia wyczerpania: a) kolana po 228 tys. godzin eksploatacji ozn. $2 \mathrm{E}$, b) kolana po 127 tys. godzin eksploatacji ozn. 1LE, c) kolana po 127 tys. godzin eksploatacji ozn. 1PE 
materials of the tested elbows taken from the tension zone, the tests of yield stress $R_{e}^{550}$ (Fig. 6a) and tensile strength $R_{m}{ }^{550}$ (Fig. 6b) were carried out at a temperature of $550^{\circ} \mathrm{C}$ close to the operating temperature.

For the materials tested, impact measurements were also carried out on $\mathrm{V}$ notched specimens, which made it possible to determine impact energy, which is a measure of deformability of the tested materials after use. Fig. 7 shows the results of impact energy at room temperature for the materials of the tested elbows. Fig. 8 shows the dependence of impact energy on the test temperature for the material of the examined elbows, which allowed to determine the temperature of transition into brittle state. In addition, Fig. 9 shows the obtained results of HV10 hardness measurement in graphic form.

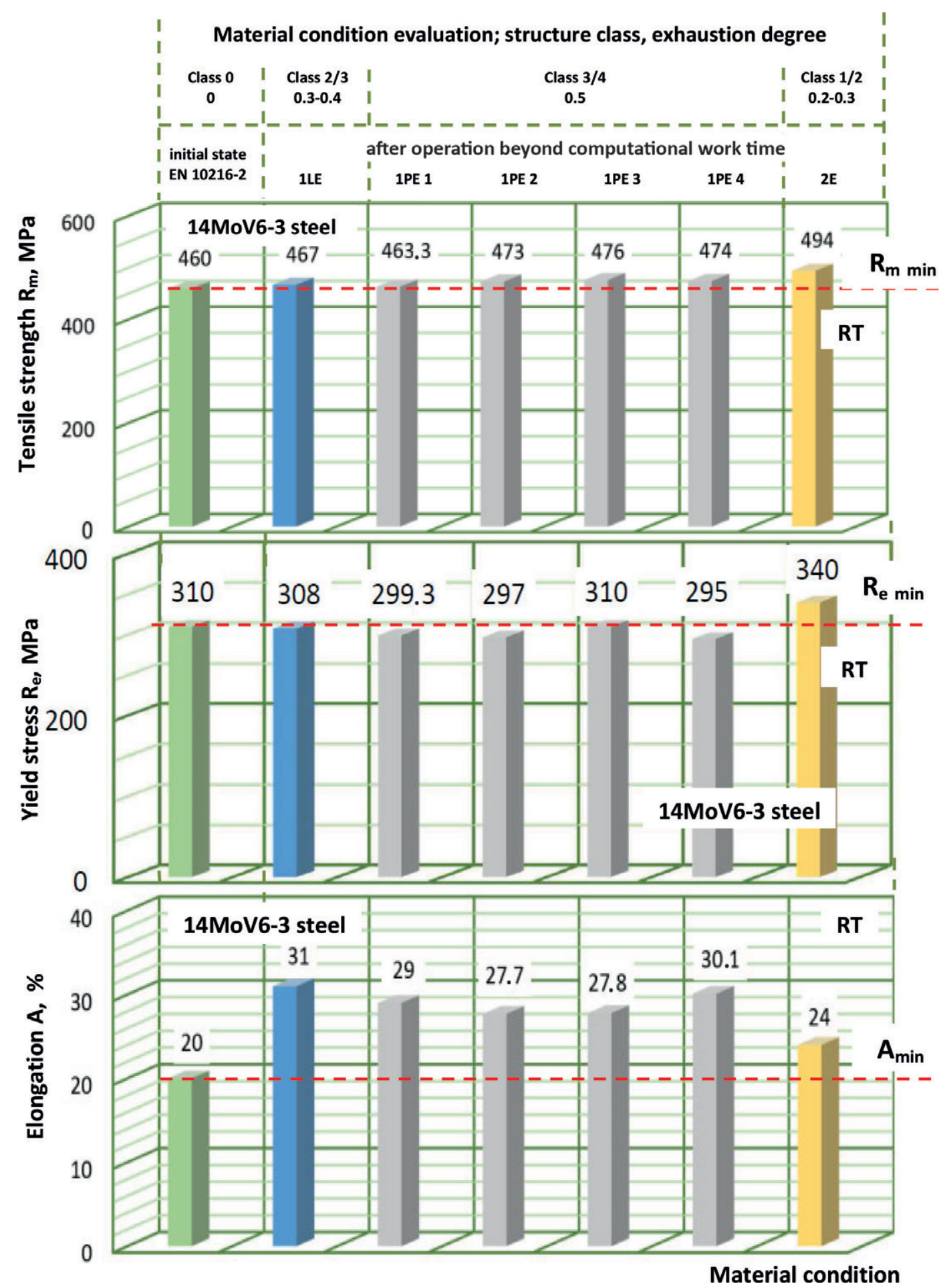

Fig. 5. Test results of strength properties at room temperature for the tested elbows and straight sections made of the 14MoV6-3 (13HMF) steel after operation in creep conditions outside the computational time in relation to the structure class and exhaustion degree: a) tensile strength $R_{m}$, b) yield stress $R_{e}$, c) elongation in tensile test $A$

Rys. 5. Wyniki badań właściwości wytrzymałościowych w temperaturze pokojowej badanych kolan i odcinków prostych ze stali 14MoV6-3 (13HMF) po eksploatacji w warunkach pełzania poza czasem obliczeniowym w odniesieniu do klasy struktury i stopnia wyczerpania: a) wytrzymałości na rozciagganie $\boldsymbol{R}_{m}$, b) granicy plastyczności Re, c) wydłużenia w próbie rozciągania A 


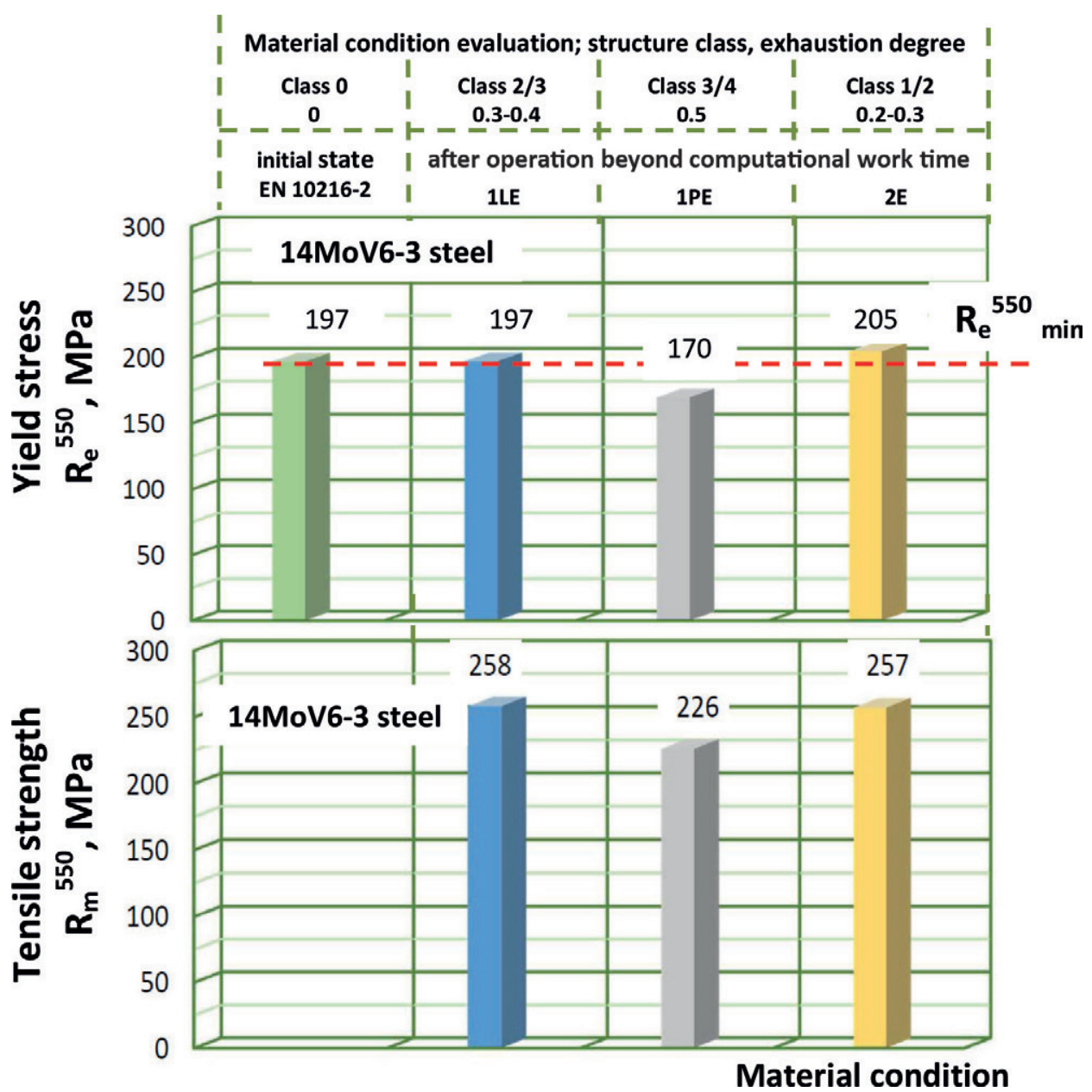

Fig. 6. Results of strength properties tests at $550^{\circ} \mathrm{C}$ for the tested elbows made of the 14MoV6-3 (13HMF) steel after use in creep conditions outside the computational time in relation to the structural class and exhaustion degree: a) yield stress $\boldsymbol{R}_{e}{ }^{550^{\circ} \mathrm{C}}$, b) tensile strength $\boldsymbol{R}_{m}{ }^{550^{\circ} \mathrm{C}}$

Rys. 6. Wyniki badań właściwości wytrzymałościowych w temperaturze $550^{\circ} \mathrm{C}$ badanych kolan ze stali $14 \mathrm{MoV6-3}$ (13HMF) po eksploatacji $w$ warunkach pełzania poza czasem obliczeniowym $w$ odniesieniu do klasy struktury i stopnia wyczerpania: a) granicy plastyczności $R_{e}^{550^{\circ} \mathrm{C}}$, b) wytrzymałości na rozciąganie $R_{m}{ }^{550^{\circ} \mathrm{C}}$

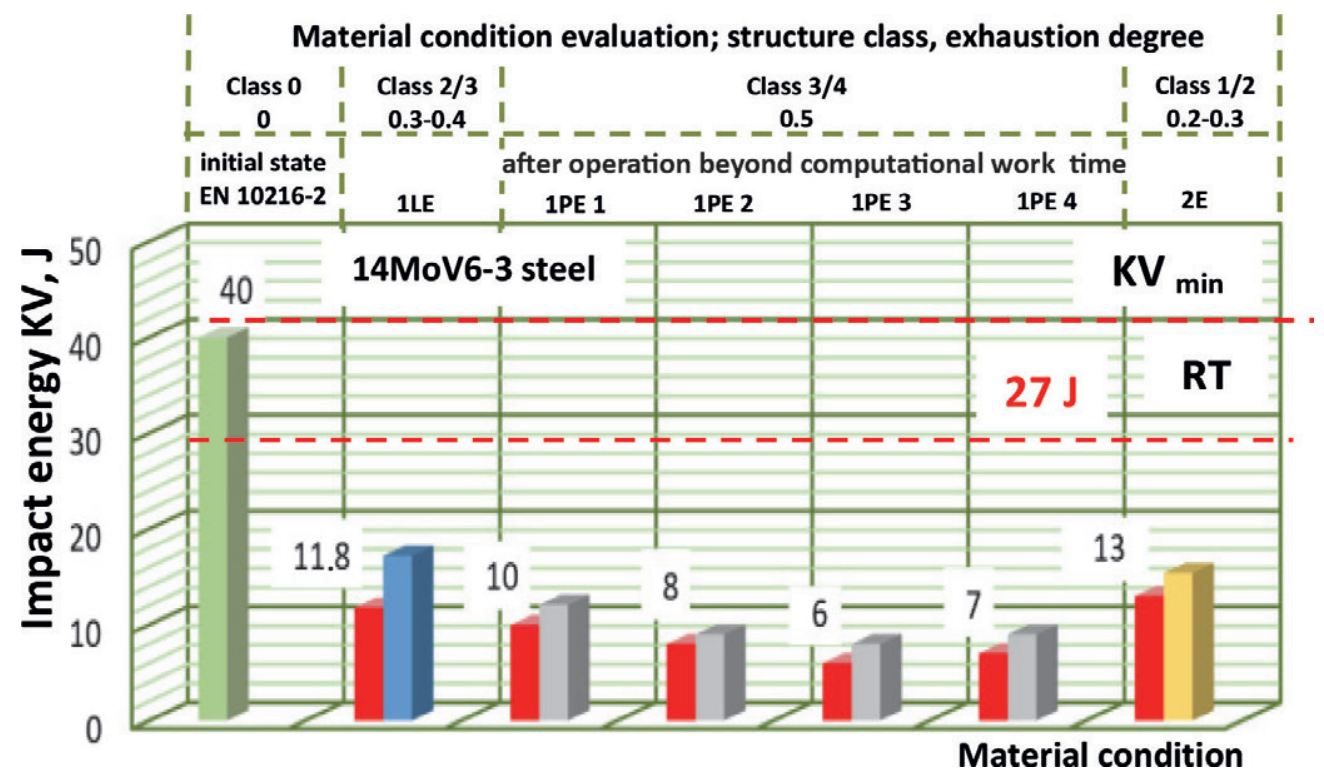

Fig. 7. Results of impact energy tests at room temperature of the tested elbows and straight sections made of the 14MoV6-3 steel (13HMF) after operation in creep conditions outside the computational time in relation to the structure class and degree of exhaustion

Rys. 7. Wyniki badań pracy lamania w temperaturze pokojowej badanych kolan i odcinków prostych ze stali 14MoV6-3 (13HMF) po eksploatacji w warunkach pełzania poza czasem obliczeniowym w odniesieniu do klasy struktury i stopnia wyczerpania 

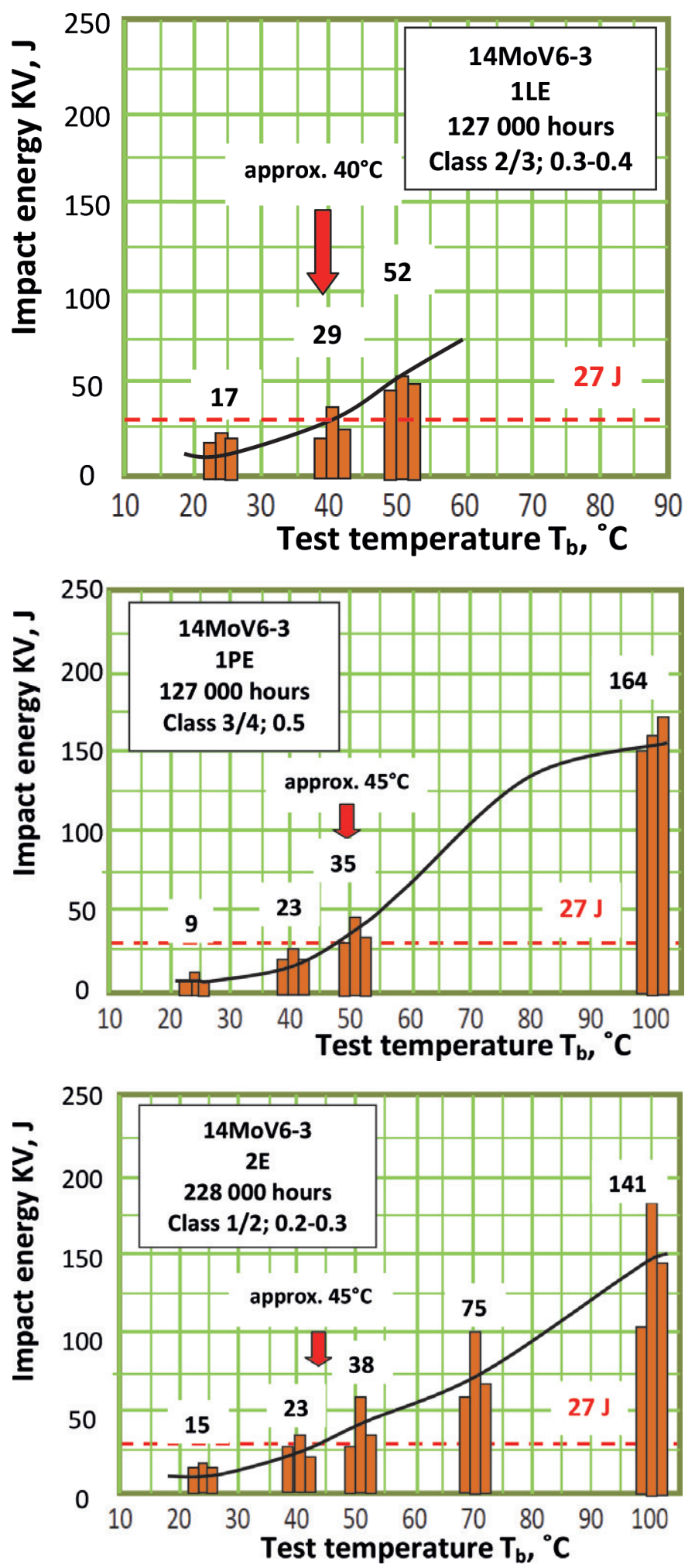

Fig. 8. Results of impact energy tests depending on the test temperature of the tested elbows made of the 14MoV6-3 steel (13HMF) after operation in creep conditions outside the computational time in relation to the structure class and degree of exhaustion

Rys. 8. Wyniki badań pracy lamania w zależności od temperatury badania materiału badanych kolan zestali 14MoV6-3 (13HMF) po eksploatacji w warunkach pełzania poza czasem obliczeniowym w odniesieniu do klasy struktury i stopnia wyczerpania

All test results were referenced to the designated class of structure and the corresponding estimated degree of exhaustion. The test results were also referenced to the minimum values required for the material in the initial state. Tensile strength at room tempera- ture $R_{m}$ of all materials tested after operation is higher, and for the material after 228,000 operating hours it is clearly higher than the minimum value required for the initial condition (Fig. 5a). Yield stress at room temperature $R_{e}$ for the tested elbows and straight sec- 


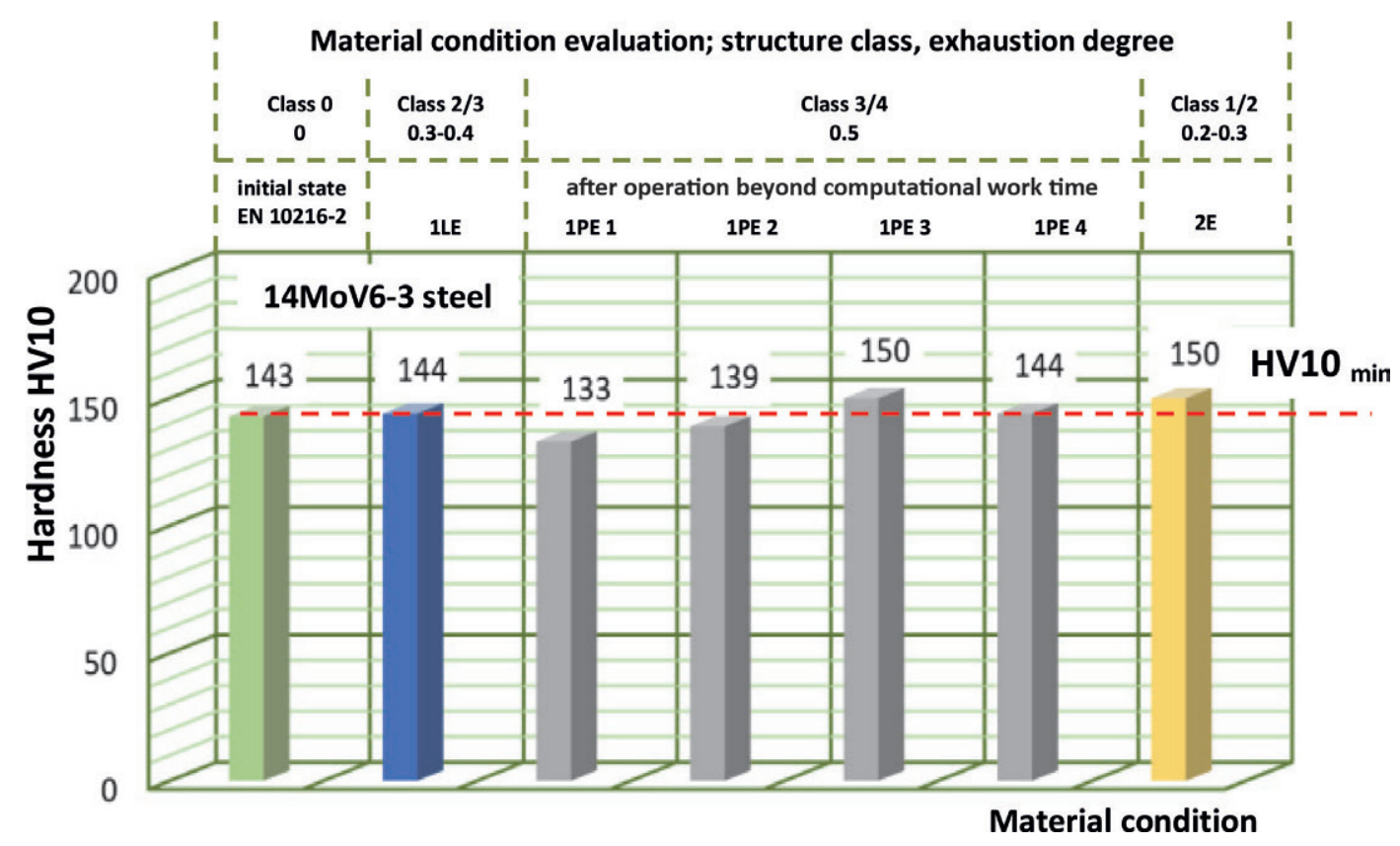

Fig. 9. Results of HV10 hardness tests of the tested elbows and straight sections made of the 14MoV6-3 steel (13HMF) after operation in creep conditions outside the computational time in relation to the structure class and degree of exhaustion

Rys. 9. Wyniki badań twardości HV10 kolan i odcinków prostych ze stali 14MoV6-3 (13HMF) po eksploatacji w warunkach pełzania poza czasem obliczeniowym w odniesieniu do klasy struktury i stopnia wyczerpania

tions after 127,000 operating hours is slightly lower than the minimum value required for the initial state, while for the material after operation for 228,000 hours it is clearly higher than this value (Fig. 5b). The elongation results obtained in the tensile test are much higher than the required minimum value, while the lowest is the value for the material after 228,000 operating hours (Fig. 5c), which correlates with the results of tensile strength and yield stress (Fig. 5a, b). The results of yield stress tests of the material of the tested elbows carried out at $550^{\circ} \mathrm{C}$ for elbow $2 \mathrm{E}$ after
228,000 operating hours are above this value, for $1 \mathrm{LE}$ after 127,000 hours they are at the level of the required minimum value, and for $1 \mathrm{PE}$ after 127,000 operating hours they are well below this value (Fig. 6a). Similar relations were revealed for the determined values of tensile strength at this temperature (Fig. 6b).

The analysis of the obtained values of impact energy allowed to conclude that for all the tested materials after operation, elbows and straight sections, it is not only much below the required value for the initial state but also below the expected value of $27 \mathrm{~J}$ correspond-

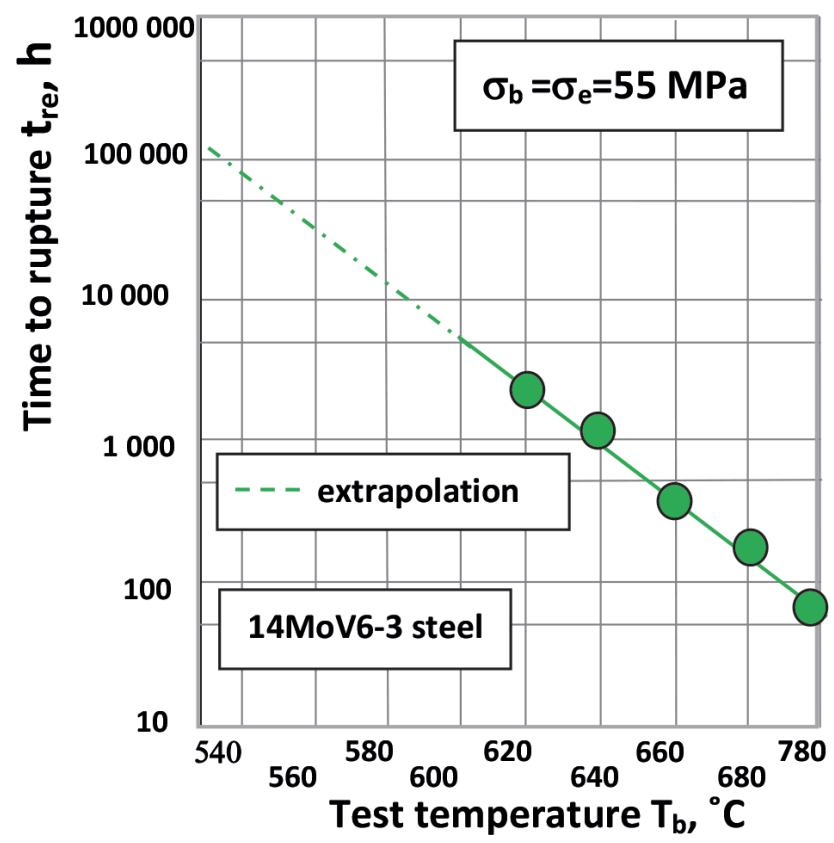

Fig. 10. Example of the results of short creep tests in the form of the $\log t_{r}=\mathbf{f}\left(\mathrm{T}_{\mathrm{b}}\right)$ relationship at $\sigma_{b}=\sigma_{e \text { max }}$ of the live steam pipeline elbow material made of the 14MoV6-3 steel after 127,000 working hours under creep conditions

Rys. 10. Przykład wyników badań skróconych prób pełzania w postaci zależności log $t_{r}=f\left(T_{b}\right)$ przy $\sigma_{b}=\sigma_{e m a x}$ materiału kolana rurociąu pary świeżej ze stali 14MoV6-3 po 127 tys. godzin eksploatacji w warunkach pełzania 
ing to $50 \% / 50 \%$ of ductile and brittle fracture (Fig. 7). In addition, the temperature of the transition into brittle state for the material of the three tested elbows, determined in Fig. 8, is positive and amounts to respectively: for the $1 \mathrm{LE}$ elbow material after 127,000 operating hours approx. $+40^{\circ} \mathrm{C}$ (Fig. $8 \mathrm{a}$ ) and for the other two elbow materials: $1 \mathrm{PE}$ after 127,000 operating hours and $2 \mathrm{E}$ after 228,000 operating hours, approx. $+45^{\circ} \mathrm{C}$ (Fig. $8 \mathrm{~b}, \mathrm{c}$ ).

The hardness of the materials of the tested elbows and straight sections after 127,000 hours is at the level of the minimum expected value for the material in the initial state or slightly below, and clearly above for the material of the elbow after 228,000 operating hours (Fig. 9).

All obtained test results of mechanical properties and hardness correlate with the revealed image of the structure and its assigned class and estimated degree of exhaustion. The higher the structure class and the higher the degree of exhaustion, the lower the values obtained for particular strength and hardness indices.

The most important property that decides about usability is creep resistance. It was assumed that its measure is durability defined as the time to break for given temperature and stress parameters. In order to determine it, shortened creep tests are carried out under test stress $\sigma_{\mathrm{b}}$ corresponding to operating stress $\sigma_{e}\left(\sigma_{b}=\sigma_{e}\right)$ and at test temperature levels $T_{b}$ corresponding to a temperature higher than operating temperature $T_{e}$. Extrapolation of the obtained test results at five temperature levels to the temperature corresponding to the operating temperature, by determining the straight line, allows to determine the durability of the materials in the initial state or residual life for used materials, in accordance with the procedure developed and verified by IMŻ. [10]. The results obtained from tests carried out at IMŻ for to the material after operation from elbow $1 \mathrm{LE}$ are shown in the form of dependence $\log t_{r}=f\left(T_{b}\right)$ at $\sigma_{b}=\sigma_{e \max }=55 \mathrm{MPa}=$ const in Fig. 10. The determined residual life of the tested material for the operating temperature $T_{e}=540^{\circ} \mathrm{C}$ is approx. 110,000 hours.

\section{STRUCTURE AND MECHANICAL PROPERTIES AFTER OPERATION AND REVITALISING HEAT TREATMENT}

For the revitalising heat treatment of the tested materials after long-term operation under creep conditions, the austenitising temperature during normalisation, as well as the tempering temperature were selected in accordance with the applied technological practice for the tested steel 14MoV6-3 [4]. Heating rates for these procedures and the cooling method after normalisation were also consistent with the practice used. The cooling agent after normalisation was calm air. Normalisation temperature was $950 \pm 10^{\circ} \mathrm{C}$, and tempering temperature was $730-10^{\circ} \mathrm{C}$. For pipe sections approximately $30 \mathrm{~mm}$ thick, taken from the live steam pipeline after 127,000 working hours identified as 1PE, normalising heating times were: 30', 60', 90 ' and 120'. It should be noted that the standard annealing time during normalisation, according to technological practices, is $1 \mathrm{~min}$ per $1 \mathrm{~mm}$ thickness, i.e. in this case 30 minutes. Annealing time during tempering is usually approximately $3 \mathrm{~min} / \mathrm{mm}$. However, for all heat treated sections after long-term use, 150' were

Table 2. Assessment of microstructure and the degree of development of precipitation processes of carbides of the tested elbow material made of the 14MoV6-3 steel after long-term use in creep conditions beyond computational working time as well as use and revitalising heat treatment

Tabela 2. Ocena mikrostruktury i stopnia rozwoju procesów wydzieleniowych węglików materiału badanego kolana ze stali 14MoV6-3 po długotrwałej eksploatacji w warunkach pełzania poza obliczeniowym czasem pracy oraz eksploatacji i rewitalizującej obróbce cieplnej

\begin{tabular}{|c|c|c|c|c|c|c|c|c|}
\hline \multirow{2}{*}{ 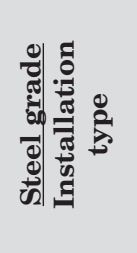 } & \multirow{2}{*}{ 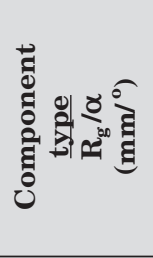 } & \multirow{2}{*}{ •월 \& } & \multirow{2}{*}{ 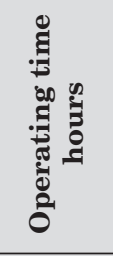 } & \multirow{2}{*}{ 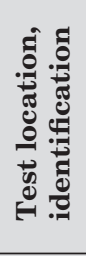 } & \multirow{2}{*}{ 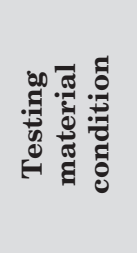 } & \multirow{2}{*}{ 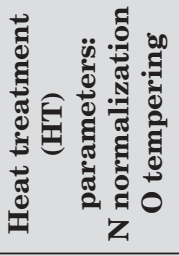 } & $\begin{array}{c}\text { Phase } \\
\text { composition of } \\
\text { precipitates }\end{array}$ & \multirow{2}{*}{ 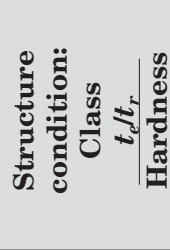 } \\
\hline & & & & & & & $\begin{array}{c}\text { Precipitates } \\
\text { development state } \\
\text { class }\end{array}$ & \\
\hline 1 & 2 & 3 & 4 & 5 & 6 & 7 & 8 & 9 \\
\hline \multirow{10}{*}{$\begin{array}{l}\text { 14MoV6-3 } \\
\frac{(13 \mathrm{HMF})}{\text { live steam }} \\
\text { pipeline }\end{array}$} & \multirow{10}{*}{$\begin{array}{l}\frac{\text { Elbow }}{1500 / 45} \\
\text { right side }\end{array}$} & \multirow{10}{*}{$\begin{array}{c}355.6 \\
\times 47\end{array}$} & \multirow{10}{*}{127,000} & \multirow{10}{*}{ 1PE 1} & \multirow{2}{*}{$\begin{array}{c}\text { after } \\
\text { operation }\end{array}$} & \multirow[t]{2}{*}{ without HT } & $\begin{array}{c}\mathrm{M}_{6} \mathrm{C}+\mathrm{MC}+ \\
\mathrm{M}_{23} \mathrm{C}_{6}\end{array}$ & \multirow{2}{*}{$\begin{array}{c}\text { Class } 3 / 4 \\
\underline{0.5} \\
133\end{array}$} \\
\hline & & & & & & & Class a/b & \\
\hline & & & & & \multirow{2}{*}{$\begin{array}{c}\text { after } \\
\text { operation } \\
\text { + HT1 }\end{array}$} & \multirow{2}{*}{$\begin{array}{l}\text { N 30' } \\
\text { O 150' }\end{array}$} & $\begin{array}{c}\mathrm{M}_{3} \mathrm{C}+\mathrm{MC}+ \\
\mathrm{M}_{23} \mathrm{C}_{6}\end{array}$ & \multirow{2}{*}{$\begin{array}{c}\text { Class } 1 \\
\underline{0.2} \\
150\end{array}$} \\
\hline & & & & & & & Class a & \\
\hline & & & & & \multirow{2}{*}{$\begin{array}{c}\text { after } \\
\text { operation } \\
\text { + HT2 }\end{array}$} & \multirow[t]{2}{*}{$\begin{array}{l}\text { N 60' } \\
\text { O 150' }\end{array}$} & $\begin{array}{c}\mathrm{M}_{3} \mathrm{C}+\mathrm{MC}+ \\
\mathrm{M}_{23} \mathrm{C}_{6}\end{array}$ & \multirow{2}{*}{$\begin{array}{l}\text { Class } 0 / 1 \\
\text { to } 0.2 \\
168\end{array}$} \\
\hline & & & & & & & Class a & \\
\hline & & & & & \multirow{2}{*}{$\begin{array}{c}\text { after } \\
\text { operation } \\
\text { + HT3 }\end{array}$} & \multirow[t]{2}{*}{$\begin{array}{l}\text { N 90' } \\
\text { O 150' }\end{array}$} & $\begin{array}{c}\mathrm{M}_{3} \mathrm{C}+\mathrm{MC}+ \\
\mathrm{M}_{23} \mathrm{C}_{6}\end{array}$ & \multirow{2}{*}{$\begin{array}{l}\text { Class } 0 / 1 \\
\text { to } 0.2 \\
157\end{array}$} \\
\hline & & & & & & & Class o/a & \\
\hline & & & & & \multirow{2}{*}{$\begin{array}{c}\text { after } \\
\text { operation } \\
\text { + HT4 }\end{array}$} & \multirow{2}{*}{$\begin{array}{l}\text { N 120' } \\
\text { O 150' }\end{array}$} & $\begin{array}{c}\mathrm{M}_{3} \mathrm{C}+\mathrm{MC}+ \\
\mathrm{M}_{23} \mathrm{C}_{6} \\
\end{array}$ & \multirow{2}{*}{$\begin{array}{l}\text { Class } 0 / 1 \\
\text { to } 0.2 \\
160\end{array}$} \\
\hline & & & & & & & Class o/a & \\
\hline
\end{tabular}


assumed; the decision was based on the state of the structure and its degradation degree.

For the sections of the material taken from the 1PE elbow, heat treatment parameters varied with annealing time during the normalisation procedure; the annealing temperature was constant, the tempering temperature and the holding time were the same. For the sections of elbows $1 \mathrm{LE}$ and $2 \mathrm{E}$, the temperatures mentioned above and the heat treatment times were constant.

In order to demonstrate the effectiveness of the above-mentioned heat treatment procedures in the recovery of structure and mechanical properties, the results obtained for the material of elbow $1 \mathrm{PE}$, whose degree of structure degradation after operation was the greatest, are shown.

Firstly, the state of the structure was evaluated in the examined elbow material after operation and revitalising heat treatment. The results obtained on the basis of observations with a scanning electron microscope and the identification of precipitates based on X-ray phase composition analysis of electrolytically isolated carbide deposits are presented in Table 2.
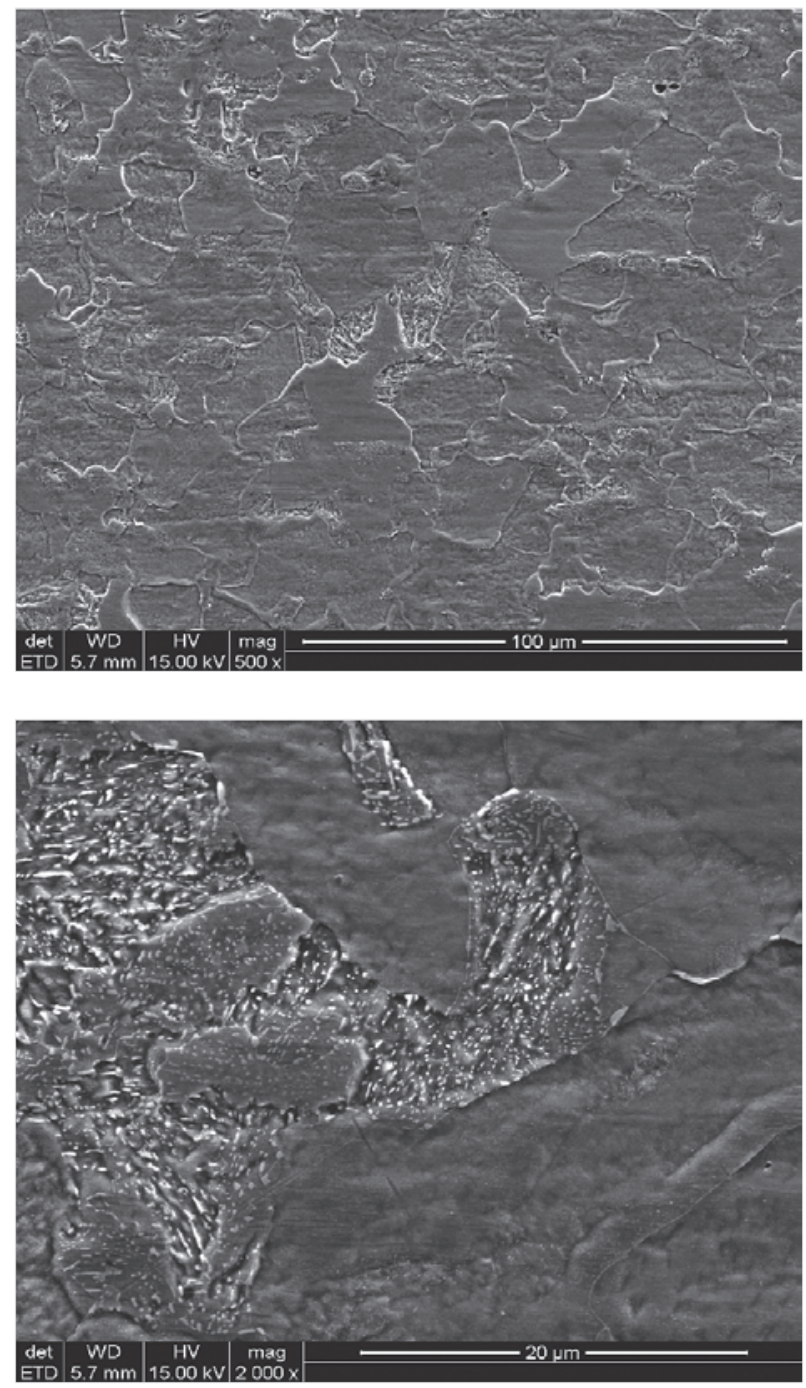

An example of a typical obtained image of the material structure after operation and revitalising heat treatment is shown in Fig. 11. This structure is similar in character to the initial state. It is a mixture of ferrite with bainite as well as pearlite and individual small precipitates on ferrite grain boundaries.

The obtained mechanical properties for the material with such structure after a revitalising heat treatment at an identical temperature but with different holding times during normalisation and with identical tempering parameters are shown in Fig. 12-15. Fig. 12 shows the results of strength tests at room temperature in graphical form. Fig. 12a shows the results of tensile strength $R_{m}$, in Fig. $12 \mathrm{~b}-$ yield stress $R_{e}$, and in Fig. 12c - elongation in tensile test A. The results of tensile strength and yield stress tests at $550^{\circ} \mathrm{C}$, similar to the service life parameters, are shown in Fig. 13. Fig. 14 presents the results of impact energy tests, and Fig. 15 presents the dependence of impact energy on the test temperature and the determined level of temperature of transition into brittle state in relation to the values obtained for the material after operation. The results of hardness measurement of the material after operation and the applied variants of revitalising
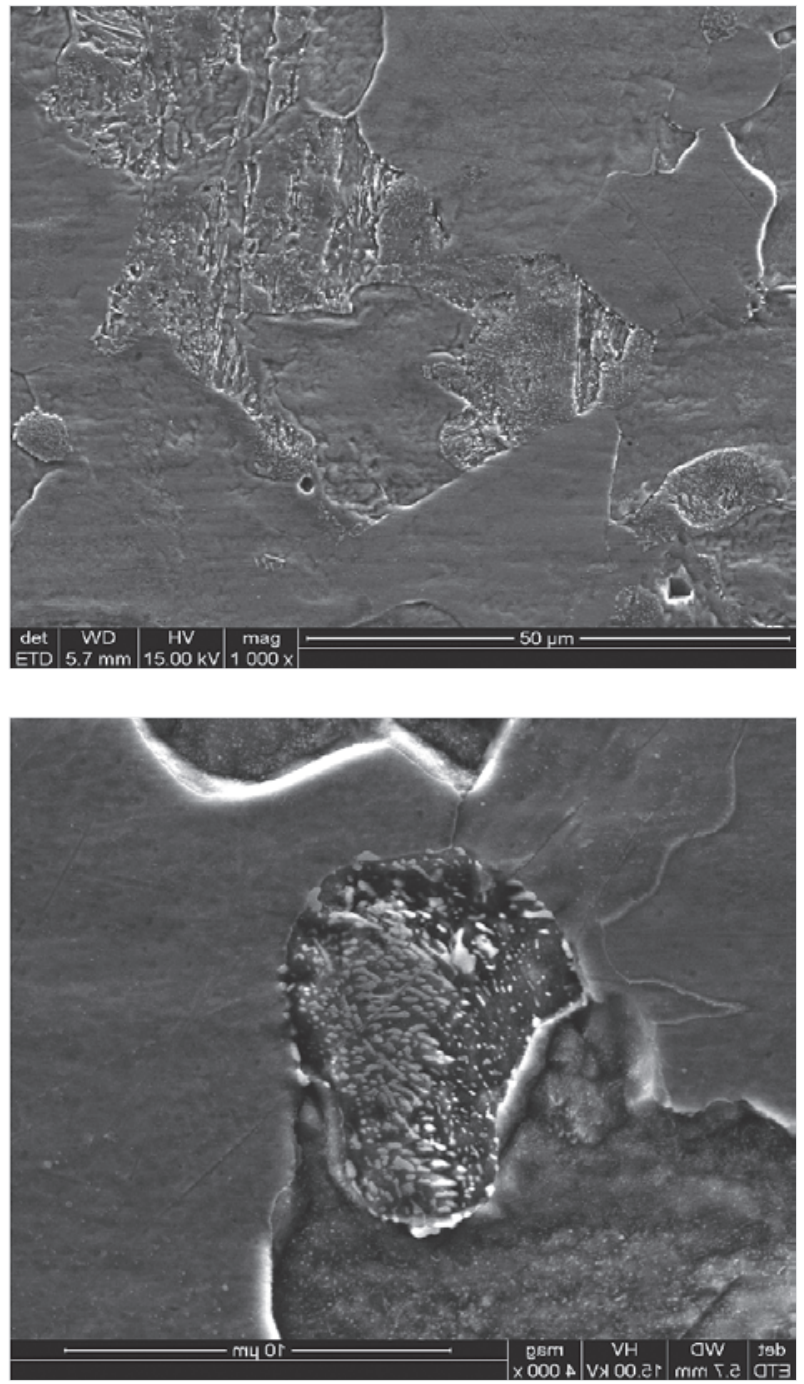

Fig. 11. Typical microstructure of the material of the tested elbow 1PE made of steel 14MoV6-3 (13HMF) after 127,000 working hours under creep conditions and revitalising heat treatment observed with a scanning electron microscope

Rys. 11. Obraz typowej mikrostruktury materiału badanego kolana ozn. 1PE ze stali 14MoV6-3 (13HMF) po 127 tys. h eksploatacji w warunkach pełzania i rewitalizującej obróbce cieplnej obserwowanej w skaningowym mikroskopie elektronowym 


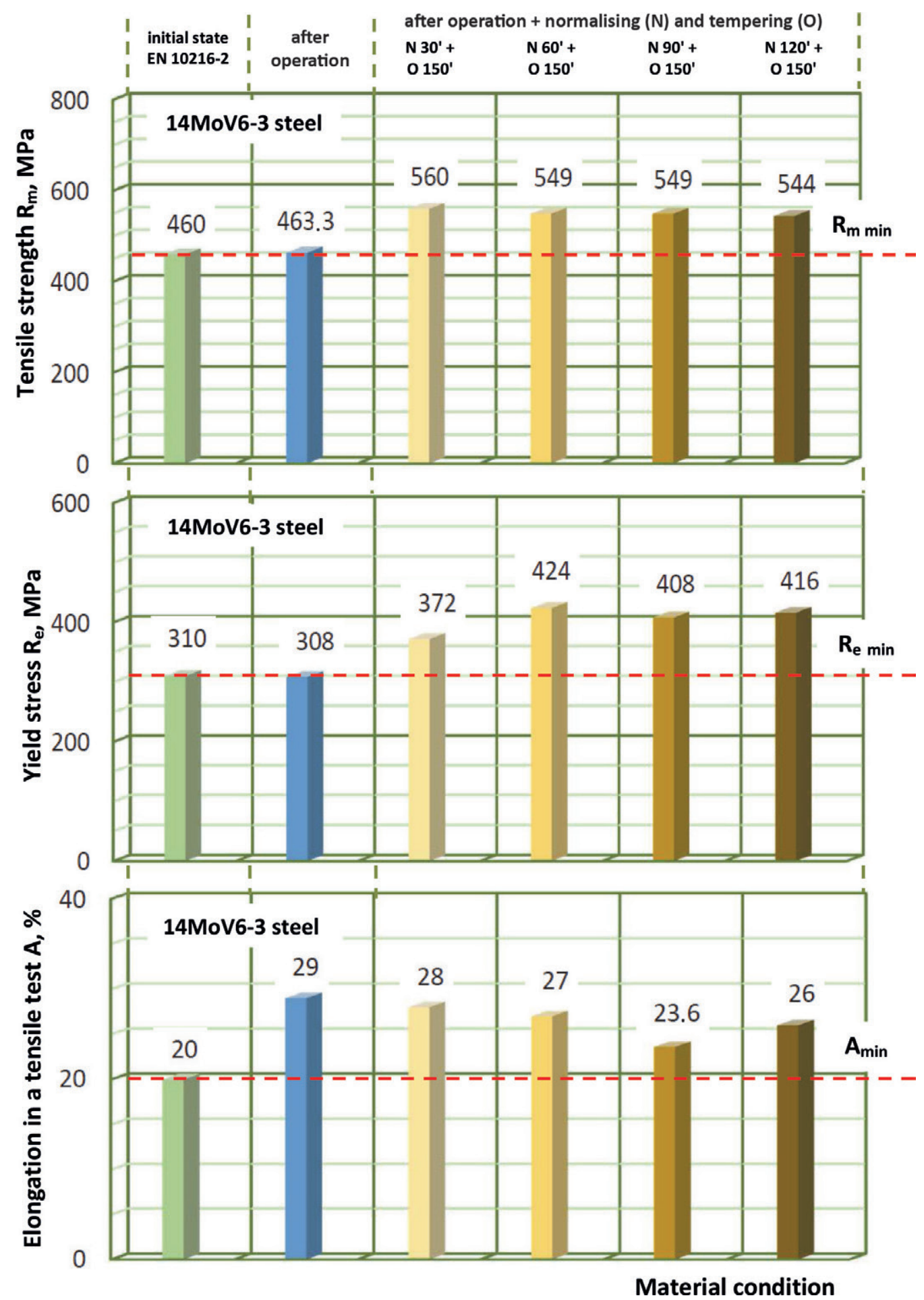

Fig. 12. Results of strength properties tests at room temperature of the tested elbow material 1PE made of the 14MoV6-3 (13HMF) steel after operation and revitalising heat treatment at identical normalisation temperature but with different holding times and identical conditions of subsequent tempering: a) tensile strength $R_{m}$, b) yield strength $R_{e}$, c) elongation in tensile test $\mathrm{A}$

Rys. 12.Wyniki badań właściwości wytrzymałościowych w temperaturze pokojowej badanego materiału kolana ozn. 1PE ze stali 14MoV6-3 (13HMF) po eksploatacji i rewitalizujacej obróbce cieplnej w identycznej temperaturze normalizowania ale o różnych czasach wytrzymania oraz identyeznych warunkach późniejszego odpuszczania: a) wytrzymałości na rozciąganie $\boldsymbol{R}_{m}$, b) granicy plastyczności $\left.\boldsymbol{R}_{e}, \mathbf{c}\right)$ wydłużenia w próbie rozciagania $\mathrm{A}$

heat treatment in relation to the condition after operation are shown in Fig. 16.

All test results were referenced to the designated class of structure and the corresponding estimated degree of exhaustion. Both the structure class defined as $0 / 1$ to 1 and the degree of exhaustion to 0.2 confirm that the obtained material, irrespective of the differ- ence in the parameters of the applied revitalising heat treatment, does not differ in structure from that characteristic for the initial state of the tested steel. The obtained results of mechanical properties tests were referenced to the minimum values required for the material in the initial state. The obtained yield strength values, both at room temperature $R_{e}$ and the increased 


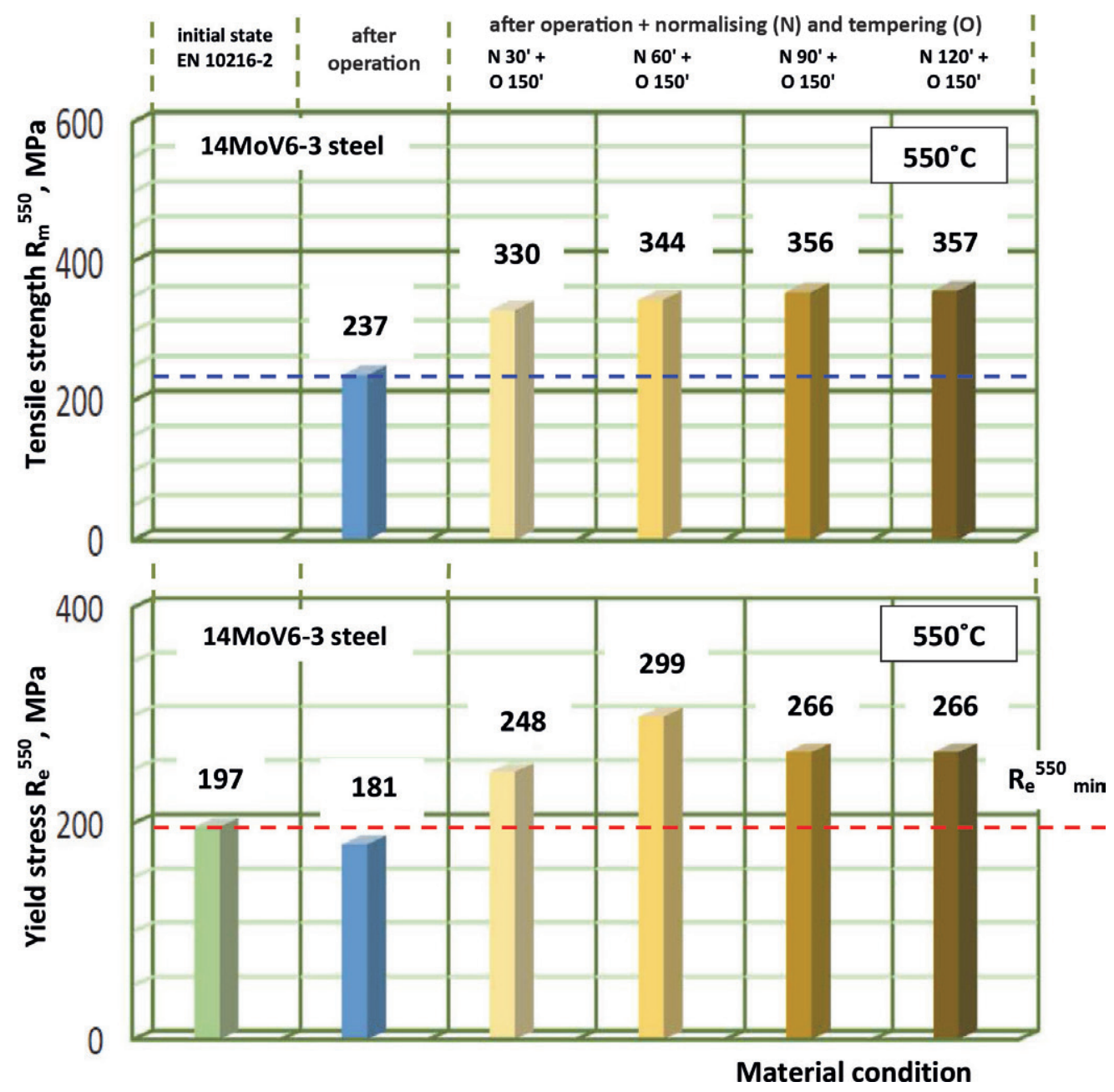

Fig. 13. Results of strength properties tests at $550^{\circ} \mathrm{C}$ of the tested elbow material 1PE made of the 14MoV6-3 (13HMF) steel after operation and revitalising heat treatment at identical normalisation temperature but with different holding times and identical conditions of subsequent tempering: a) yield strength $R_{e}{ }^{550^{\circ} \mathrm{C}}$, b) tensile strength $R_{m}{ }^{550^{\circ} \mathrm{C}}$

Rys. 13. Wyniki badań właściwości wytrzymałościowych w temperaturze $550^{\circ} \mathrm{C}$ badanego materiału kolana ozn. 1PE ze stali 14MoV6-3 (13HMF) po eksploatacji i rewitalizującej obróbce cieplnej w identycznej temperaturze normalizowania ale o różnych czasach wytrzymania oraz identycznych warunkach późniejszego odpuszczania: a) granicy plastyczności $R_{e}^{550^{\circ} \mathrm{C}}$, b) wytrzymałości na rozciaganie $R_{m}^{550^{\circ} \mathrm{C}}$

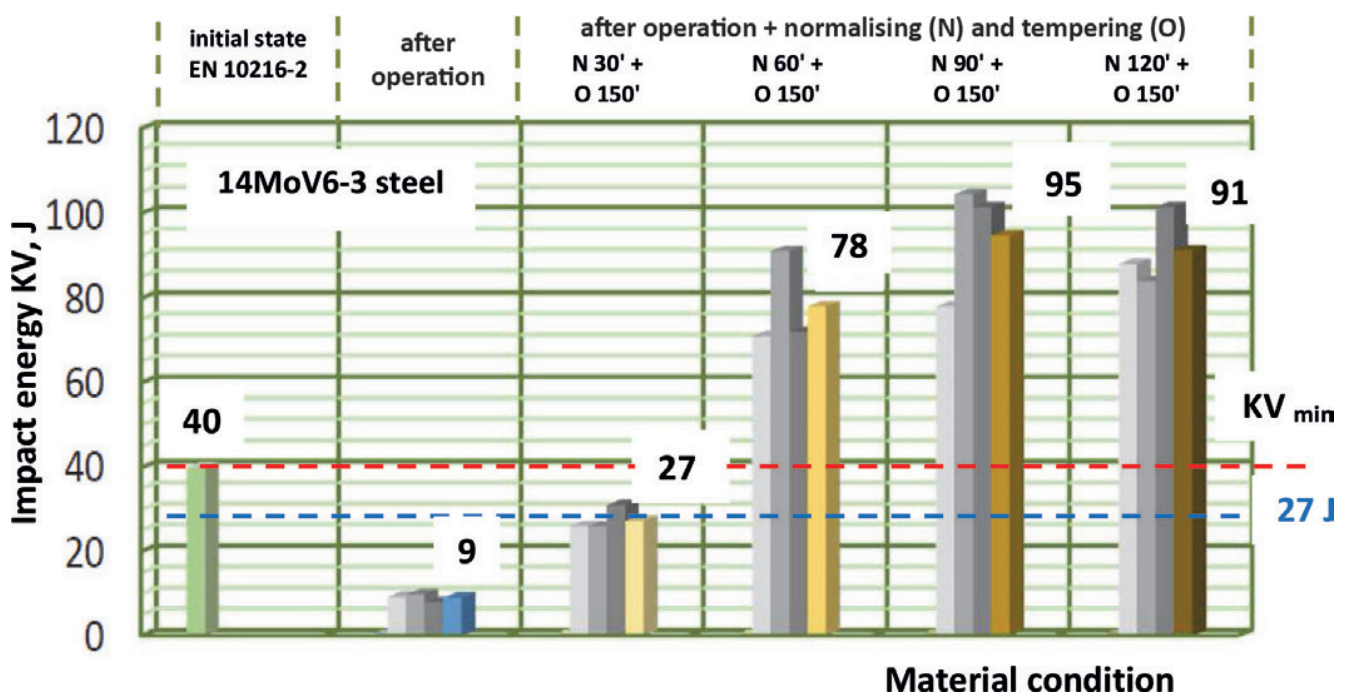

Fig. 14. Results of impact energy tests at room temperature of the tested elbow material 1PE made from the 14MoV6-3 (13HMF) steel after operation and revitalising heat treatment at identical normalisation temperature but with different holding times and identical conditions of subsequent tempering

Rys. 14. Wyniki badań pracy lamania w temperaturze pokojowej materiału kolana ozn. 1PE ze stali 14MoV6-3 (13HMF) po eksploatacji i rewitalizującej obróbce cieplnej w identycznej temperaturze normalizowania ale o różnych czasach wytrzymania oraz identycznych warunkach późniejszego odpuszczania 
$R_{e}^{550^{\circ} \mathrm{C}}$, are much higher than the minimum values required for the initial state (Fig. 12b, 13b).

Tensile strength at room temperature $R_{m}$ also fulfils the requirements for the initial state of the tested steel (Fig. 12a), and at an elevated temperature $R_{m}{ }^{550^{\circ} \mathrm{C}}$, it is much higher than that obtained for the condition after operation (Fig. 13a). The obtained results of elongation in the tensile test of the material after revitalising heat treatment are higher than the required minimum value for the initial state, but lower than that obtained for the material after operation (Fig. 12c).
The analysis of the obtained values of impact energy allowed to conclude that for all the tested materials after operation and revitalising heat treatment, values higher than those obtained for the material after operation were obtained. The lowest values at the level of the expected minimum value of $27 \mathrm{~J}$ were obtained for the heat treatment variant with the shortest normalisation time applied. After other applied variants of revitalising heat treatment, the material was characterised by an impact energy of more than twice the minimum value required for the material in the initial
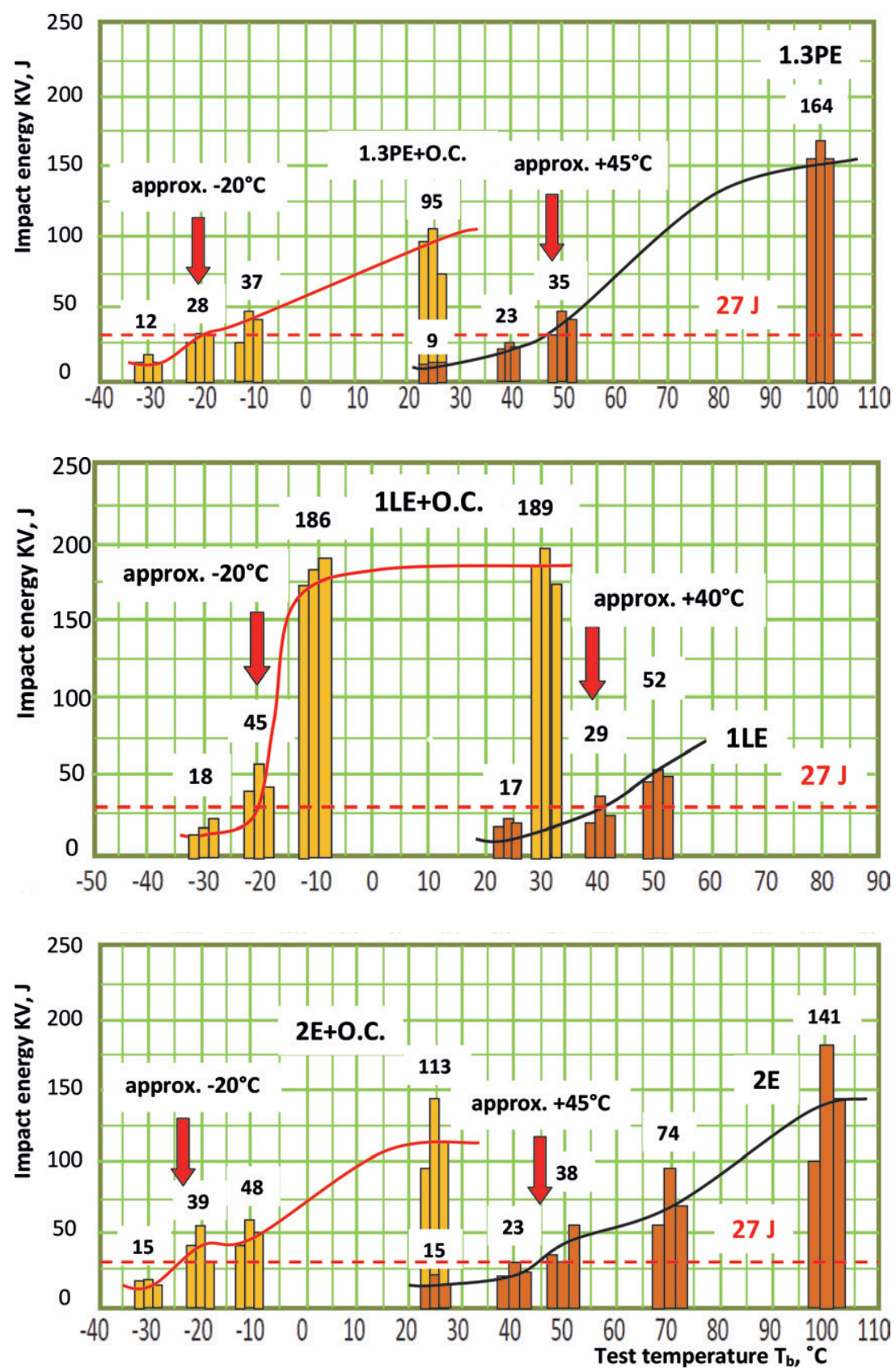

Fig. 15. Examples of impact energy test results depending on the material testing temperature of the tested elbows made of steel 14MoV6-3 (13HMF) after operation in creep conditions with respect to these materials after operation and revitalising heat treatment: a) $1.3 \mathrm{PE}$ after 127,000 working hours and operation and revitalising heat treatment, b) $1 \mathrm{LE}$ after 127,000 working hours in creep conditions and operation and revitalising heat treatment, c) $2 \mathrm{E}$ after 228,000 working hours in creep conditions and operation and revitalising heat treatment

Rys. 15. Przykłady wyników badań pracy lamania w zależności od temperatury badania materiału badanych kolan ze stali 14MoV6-3 (13HMF) po eksploatacji w warunkach pełzania w odniesieniu do tych materiałów po eksploatacji i rewitalizującej obróbce cieplnej: a) ozn. 1.3PE po 127 tys. godzin eksploatacji oraz eksploatacji i rewitalizującej obróbce cieplnej, b) ozn. 1LE po 127 tys. godzin eksploatacji w warunkach pełzania oraz eksploatacji i rewitalizującej obróbce cieplnej, c) ozn. 2E po 228 tys. godzin eksploatacji w warunkach pełzania oraz eksploatacji i rewitalizującej obróbce cieplnej 


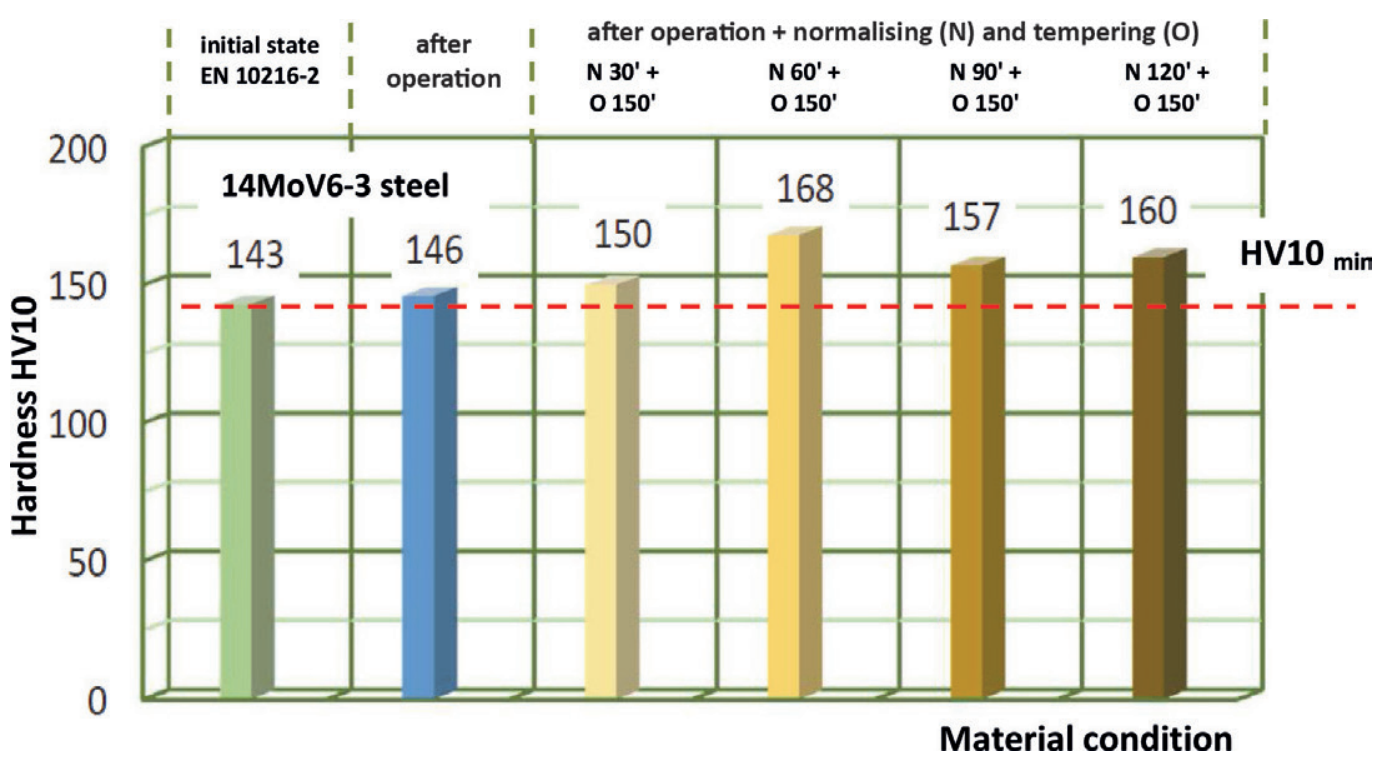

Fig. 16. Results of HV10 hardness measurement of the tested elbow material 1PE made of the 14MoV6-3 (13HMF) steel after operation and revitalising heat treatment at identical normalisation temperature but with different holding times and identical conditions of subsequent tempering

Rys. 16. Wyniki badań twardości HV10 badanego materiału kolana ozn. 1PE ze stali 14MoV6-3 (13HMF) po eksploatacji i rewitalizującej obróbce cieplnej w identycznej temperaturze normalizowania ale o różnych czasach wytrzymania oraz identycznych warunkach późniejszego odpuszczania

state (Fig. 14). In addition, revitalising heat treatment caused a shift in the temperature of transition to brittle state from approx. $+45^{\circ} \mathrm{C}$ after operation (Fig. $8 \mathrm{~b}, \mathrm{c}$ ) to a negative temperature of approx. $-20^{\circ} \mathrm{C}$ (Fig. 15).

The hardness of the tested elbow materials $1 \mathrm{PE}$ after long-term operation in creep conditions and revitalising thermal treatment is slightly higher than the minimum expected value for the material in the initial state as well as the hardness obtained for the tested material after the operation (Fig. 16).

All obtained results for mechanical properties and hardness correlate with the revealed image of the structure and its assigned grade and estimated degree of material exhaustion after operation and revitalising heat treatment, and confirm the effectiveness of the heat treatment.

Also the performed short creep tests, in accordance with the procedure developed and verified by IMŻ, described in Section 3, for the material after operation and revitalising heat treatment, confirm the effectiveness of these heat treatment procedures (Fig. 17). The comparison of residual life for an operating temperature of $540^{\circ} \mathrm{C}$ is shown in Fig. $17 \mathrm{~b}$. The residual life of the material of the tested elbow after operation $t_{r e}$ is

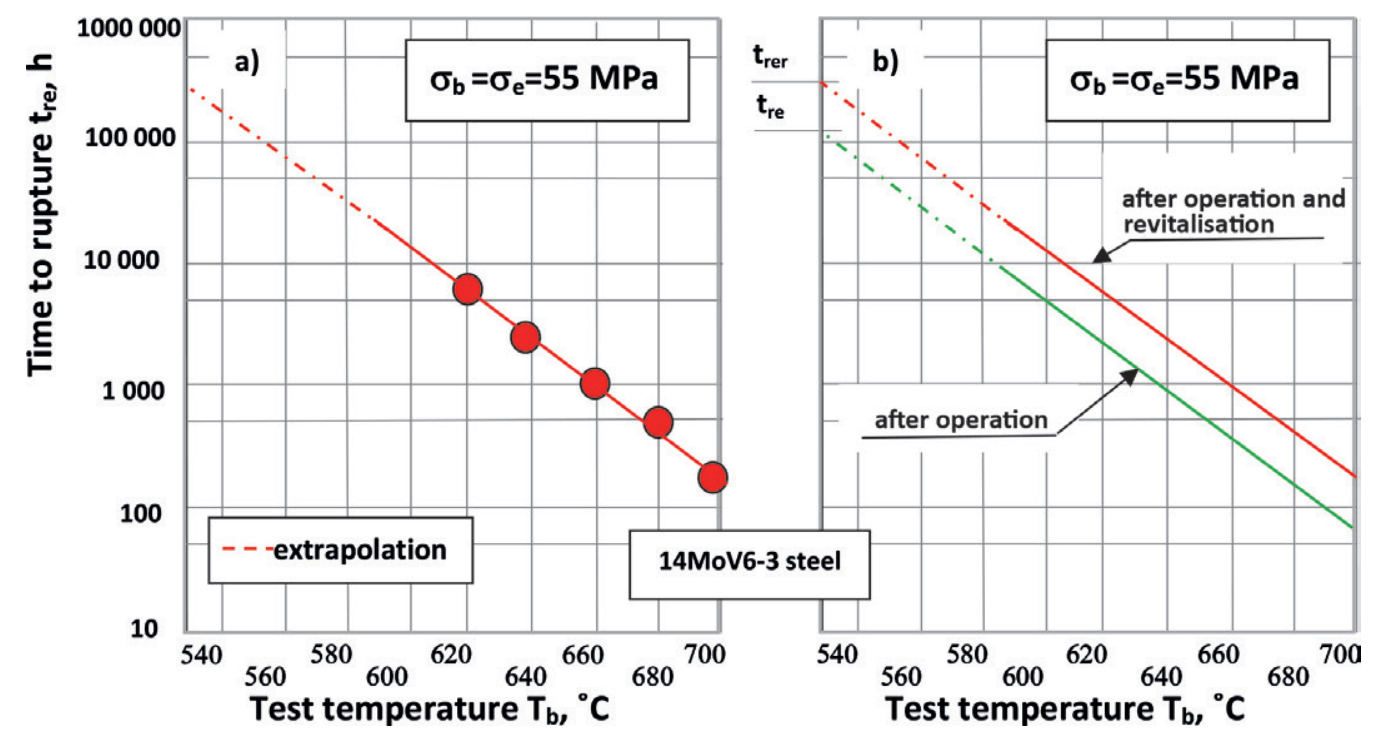

Fig. 17. Example of the results of short creep tests in the form of dependence $\log t_{r}=\mathbf{f}\left(T_{b}\right)$ at $\sigma_{b}=\sigma_{e}$ max: a) material of the live stem pipeline elbow made of the 14MoV6-3 steel after 127,000 working hours under creep conditions and revitalising heat treatment, b) comparison of the material's residual life after operation and operation and revitalising heat treatment; $t_{r e}$ - residual life, $t_{r e r}$ - life after revitalising heat treatment

Rys. 17. Przykład wyników badań skróconych prób pełzania w postaci zależności $\log t_{r}=\mathbf{f}\left(T_{b}\right)$ przy $\sigma_{b}=\sigma_{e \text { max }}$ a) materiału kolana rurociągu pary świeżej ze stali 14MoV6-3 po 127 tys. godzin eksploatacji w warunkach pełzania i rewitalizującej obróbce cieplnej, b) porównanie trwałości resztkowej materiału po eksploatacji oraz eksploatacji i rewitalizującej obróbce cieplnej; $t_{r e}$ - trwałość resztkowa; $t_{r e r}$ - trwałość po rewitalizującej O.C. 
approx. 110,000 hours, and after operation and revitalising heat treatment, life $t_{r e r}$ is approx. 320,000 hours.

\section{SUMMARY}

The presented research results concern the problem of the "recovery" of functional properties of low-alloy three-component Cr-Mo-V steels used in creep conditions above computational working time, showing significant changes in the microstructure and characterised by a significant degree of exhaustion.

Obtaining mechanical properties at the level corresponding to the requirements for the initial state of the material requires revitalising heat treatment, which allows obtaining a proper structure ensuring such a level of these properties. In order to achieve this, it is necessary to properly choose the type of heat treatment and its parameters, which must be matched to the condition of the material after operation (class of structure and degree of exhaustion).

The analysis of the state of the structure and the selection of the type and parameters of heat treatment for the tested 14MoV6-3 (13HMF) steel after long-term operation in creep conditions, characterised by a significant degree of exhaustion, made it possible to obtain the material condition, both in terms of structure and properties, similar to the initial condition through its use. This proves the effectiveness of the process of revitalisation of the tested materials made of the 14MoV6-3 steel after long-term operation significantly beyond the computational working time.
Among the set of properties, the most important was to achieve a significant improvement in creep resistance, the measure of which is residual life. It increased significantly, from approx. 100,000 to over 300,000 hours. Impact strength, with impact energy as its measure, is another significant parameter. The impact energy at room temperature after revitalising heat treatment increased from below $10 \mathrm{~J}$ to approx. $100 \mathrm{~J}$, significantly exceeding the minimum requirements for the material in the initial state $(40 \mathrm{~J})$.

However, attention should be paid to the restrictions on the operation of revitalising heat treatment, which are the condition of the structure and the corresponding degree of exhaustion. If internal damage class A or higher is found as a result of creep (according to the IMŻ classification) [2, 14-16], such treatments are not permitted and no revitalisation can be carried out.

The result of this study can bring significant economic effects in practice. The justification for this thesis may be the case of the elbow examined in this study: $\phi 219 \times 28 \mathrm{~mm}, R_{g}=1400 \mathrm{~mm}, \alpha=90^{\circ}$, made of steel 14MoV6-3. Regardless of the reasons that caused the removal of this elbow from the installation after approx. 228,000 working hours in creep conditions, it can be subjected to revitalisation. The elbow was substituted with a new one. The cost of revitalising the elbow after operation is approx. 1/5 of the cost of producing a new elbow. It should be noted that the safe service life of the material of the elbow after revitalisation is much longer than the required computational working time of the installation, which allows its re-installation. Re-installation also allows the ability of the material of the elbow after revitalisation to be joined by welding.

\section{REFERENCES}

[1]K. Sadowski. Program modernizacji bloków klasy 200 MW. "Bloki 200+"- stan aktualny. In: IV Konferencja Techniczna „Utrzymanie Ruchu - diagnostyka, remonty, modernizacje, Kazimierz Dolny, Kozienice, 7-8 March 2018.

[2] J. Dobrzański. Materiałoznawcza interpretacja trwałości stali dla energetyki. Open Access Library, 2011, Vol. 3.

[3]A. Hernas, J. Dobrzański. Trwałość i niszczenie elementów kotłów i turbin parowych. Wydawnictwo Politechniki Śląskiej, 2003.

[4]A. Zieliński, J. Dobrzański, M. Dziuba-Kałuża. Structure of welded joints of 14MoV6-3 and 13CrMo4-5 steel elements after design work time under creep conditions. Archives of Materials Science and Engineering, 2013, 61 (2), p. 69-76.

[5] M. Dziuba-Kałuża, J. Dobrzański, A. Zieliński. Mechanical properties of Cr-Mo and Cr-Mo-V low-alloy steel welded joints after long-term service under creep conditions. Archives of Materials Science and Engineering, 2013, 63 (1), p. 5-12.

[6] Polski Komitet Normalizacyjny. PN-EN 10216-2:2014-02. Seamless steel tubes for pressure purposes. Technical conditions of delivery. Part 2: Non-alloy and alloy steel tubes with specified elevated temperature properties. Warszawa: PKN, 2015.

[7] Polski Komitet Normalizacyjny. PN-EN 10222-2:2017-06. Steel forgings for pressure equipment. Part 2: Ferritic and martensitic steels with specified elevated temperatures properties. Warszawa: PKN, 2017.
[8] Instytut Metalurgii Żelaza im. S. Staszica w Gliwicach. Charakterystyki stali. Stale do pracy $w$ temperaturach podwyższonych i obniżonych. Stale dla energetyki. Katowice: Wydawnictwo Śląsk, Series D, Volume I, Section 1.

[9] K. Grzegorzewska. Metody i kryteria oceny zmian degradacyjnych w stalach stosowanych do budowy rurociągów. Prace Instytutu Energetyki. 1990 (19).

[10] I. Dzioba. Modelowanie i analiza procesu pękania $w$ stalach ferrytycznych. Kielce: Politechnika Świętokrzyska, 2012.

[11] T. Malkiewicz. Metaloznawstwo stopów żelaza. WarszawaKraków: PWN, 1976.

[12] M. Blicharski. Inżynieria Materiałowa-Stal. Warszawa: Wydawnictwo Naukowo-Techniczne, 2010.

[13] Polski Komitet Normalizacyjny. PN-H-84024:1975. Steel for elevated temprature service - grades. Warszawa: PKN, 1975.

[14] J. Dobrzański, A. Hernas. Zasady diagnostyki i oceny trwałości eksploatacyjnej elementów kotłów i rurociagów pracujacych $w$ warunkach petzania. Report No. P/XII-2/2014. Katowice: Proma, 2013 (non-published).

[15] Office of Technical Inspection. No. 1/2015. Przedmowa. In: Zasady diagnostyki $i$ oceny trwałości eksploatacyjnej elementów kotłów i rurociagów pracujących $w$ warunkach pełzania. Issue date 27.10.2015.

[16] A. Zieliński. Trwałość eksploatacyjna żarowytrzymałych stali o osnowie ferrytycznej $w$ warunkach dtugotrwałego oddziatywania temperatury. Gliwice: Instytut Metalurgii Żelaza, 2016, Monograph No. 7. 